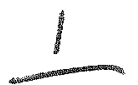

Contract No. W-7405-eng-92

\title{
THE CHARACTERISTICS OF THE BOND INTERFACE FORMED BETWEEN ZIRCALOY 2 AND URANIUM-12 w/O MOLYBDENUM
}

\section{Price $\$ 0.4 .5$}

Available from the Office of Technical Services Department of Commerce Washington 25, D. C. by

Henry A. Saller Stan J. Paprocki Edwin S. Hodge

\section{CLASSIFICATION CANCELLED DATE $\quad 2-26-57$}

For The Atomic Energy Commission

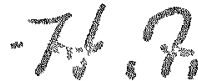
$8^{*} *$

Chief. Declassfrication brunch mel

October 17,1955

\begin{tabular}{|c|c|c|}
\hline $\begin{array}{l}\text { This rer } \\
\text { Unifed State } \\
\qquad \text { A. Mal } \\
\text { curacy, con } \\
\text { use of any } \\
\text { fringe priva } \\
\text { B. Assi }\end{array}$ & $\begin{array}{l}\text { This report was prepared as an account of work } \\
\text { sponsored by the United States Government. Neither } \\
\text { the United States nor the United States Atomic Energy } \\
\text { Commission, nor any of their employees, nor any of } \\
\text { their contractors, subcontractors, or their employees, } \\
\text { makes any warranty, express or amplied, or assumes any } \\
\text { legal liability or responsibility for the accuracy, com- } \\
\text { pleteness or usefulness of any information, apparatus, } \\
\text { product or process disclosed, or represents that its use } \\
\text { would not infringe privately owned rights. }\end{array}$ & $\begin{array}{l}\text { irk. Neither the } \\
\text { Commission: } \\
\text { 'spect to the ac- } \\
\text { eport, or that the } \\
\text { port may not in - } \\
\text { esulting from the } \\
\text { ort. }\end{array}$ \\
\hline $\begin{array}{l}\text { use of any } \\
\text { As used } \\
\text { ployee or c } \\
\text { prepares, ha } \\
\text { ployment or }\end{array}$ & $\begin{array}{l}\text { the above, "person acting on behalf of the Commission } \\
\text { ractor of the Commission to the extent that such empl } \\
\text { es or distributes, or provides access to, any information } \\
\text { ifract with the Commission. }\end{array}$ & $\begin{array}{l}\text { ort. } \\
\text { includes any em- } \\
\text { ayee or contractor } \\
\text { oursuant to his em- }\end{array}$ \\
\hline
\end{tabular}

BATTELLE MEMORIAL INSTITUTE

$505 \mathrm{King}$ Avenue

Columbus 1, Ohio 


\section{DISCLAIMER}

This report was prepared as an account of work sponsored by an agency of the United States Government. Neither the United States Government nor any agency Thereof, nor any of their employees, makes any warranty, express or implied, or assumes any legal liability or responsibility for the accuracy, completeness, or usefulness of any information, apparatus, product, or process disclosed, or represents that its use would not infringe privately owned rights. Reference herein to any specific commercial product, process, or service by trade name, trademark, manufacturer, or otherwise does not necessarily constitute or imply its endorsement, recommendation, or favoring by the United States Government or any agency thereof. The views and opinions of authors expressed herein do not necessarily state or reflect those of the United States Government or any agency thereof. 


\section{DISCLAIMER}

Portions of this document may be illegible in electronic image products. Images are produced from the best available original document. 

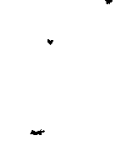


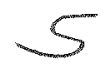

TABLE OE CONTENTS

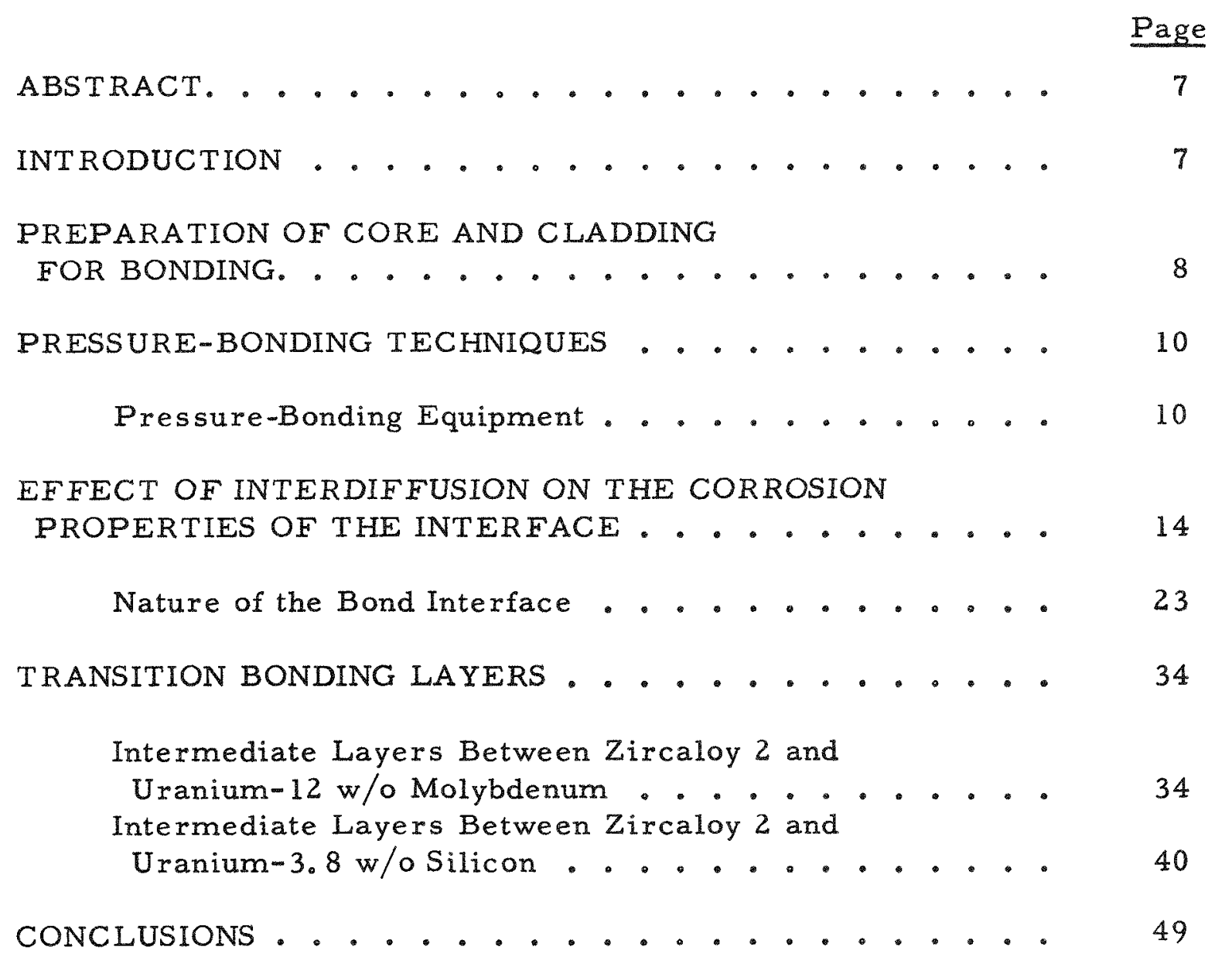




\section{CONEIDENIA L}

7

THE CHARACTERISTICS OF THE BOND INTERFACE FORMED

BETWEEN ZIRCALOY 2 AND URANIUM-12 w/o MOLYBDENUM

Henry A. Saller, Stan J. Paprocki, and Edwin S. Hodge

The interface formed between a uranium-12 w/o molybdenum core alloy and Zircaloy 2 was investigated to determine its structure and corrosion bebavior in bigb-temperature water. Assembled picture. frame-type elements were pressure bonded under conditions which yielded various degrees of interdiffusion. The bonded specimens were defected tbrough the Zircaloy 2 cladding into the alloy core uith a 40 -mil bole and corrosion tested in $650 \mathrm{~F}$ water.

Those bonds which possessed a minimum amount of diffusion were most corrosion resistant. The corrosion resistance decreased progressively with increased interdiffusion. Specimens with extensive bond diffusion failed by moturing at the interface in less than 1 br of exposure in $650 \mathrm{~F}$ water. The various alloy layers of the interface were identified and individual alloys were prepared and evaluated in bightemperature water. The alloy layers which exbibited poor corrosion resistance in the interface also possessed poor resistance wben tested as discrete alloys. The least-resistant alloys were those possessing 12 w/o molybdenum with small amounts of zirconium replacing the uranium of the base core alloy.

Transition layers between the uranium-12 w/o molybdenum core alloy and Zircaloy 2 were investigated in an effort to obtain a more resistant interface than was obtained by direct bonding. Of the layers that were investigated, chromium, platinum, and tantalum were the best, but none of these layers was sufficiently effective to warrant further study.

An exploratory study to determine the effect of different barrier layers on the interdiffusion of Zircaloy 2 and uranium-3.8 w/o silicon alloy was also made.

\section{INTRODUCTION}

A rod-type fuel element consisting of a uranium-12 w/o molybdenum core alloy clad with Zircaloy 2 was considered by WAPD for use in a pressurized-water reactor. The uranium-12 w/o molybdenum alloy appeared to be a promising core material possessing a large proportion of uranium and relatively high corrosion resistance in high-temperature pressurized water.

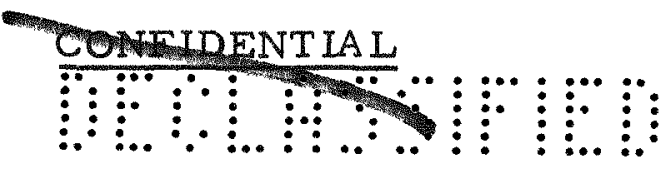




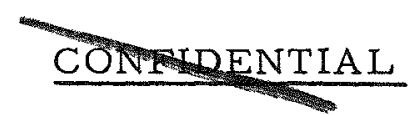

8

An extensive investigation of the corrosion properties of this alloy revealed that prolonged exposure in high-temperature water produced a spontaneous discontinuous failure. Clad specimens prepared by coextrusion and defected and corrosion tested in high-temperature water exhibited an erratic behavior. Because of these uncertainties, an investigation was requested by WAPD to determine the nature and character of the interface formed between the uranium- $12 \mathrm{w} / \mathrm{o}$ molybdenum alloy and Zircaloy 2 .

This investigation had three related objectives. The first was to determine the effect of interdiffusion on the corrosion properties of the interface. The second objective was to study the nature of the bond interface. The third was to investigate the effect of transition layers on the bonding and corrosion characteristics of the clad specimens.

In addition, an exploratory study was made of the effectiveness of various transition barrier layers on the interdiffusion between Zircaloy 2 and uranium $-3.8 \mathrm{w} / \mathrm{o}$ silicon alloy.

\section{PREPARATION OF CORE AND CLADDING FOR BONDING}

The uranium-12 w/o molybdenum core alloy was prepared by the duplex induction-consumable electrode arc-melting process. The ingots were forged at $1850 \mathrm{~F}$ and the resultant billets rolled at $1800 \mathrm{~F}$ to $0.3-\mathrm{in}$. thick plate. This plate was sectioned and machined to $1 / 4$ by 1 by 1 -in. core specimens. Portions of each ingot were analyzed and corrosion tested to verify homogeneity.

The Zircaloy 2 frames and covers were prepared from stock obtained by fabricating an ingot meeting WAPD specifications. The cores were inserted into the Zircaloy 2 frames and the assemblies were machined flush. These machined components and Zircaloy 2 cover plates were cleaned with detergent, assembled, and immediately placed in an evacuated chamber preparatory to pressure bonding. A drawing of the fuel-element components prior to assembly is shown in Figure 1. 

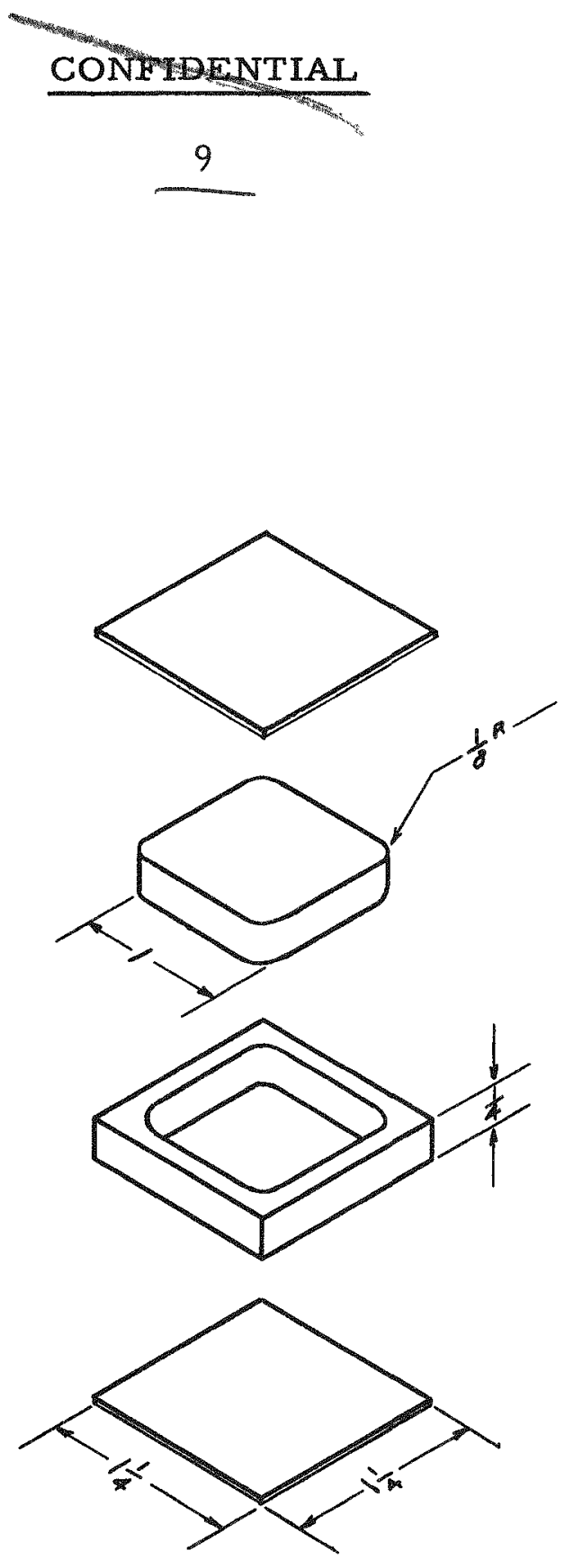

N23127

\section{FIGURE 1. EXPLODED VIEW OF FUEL ELEMENT}

Fuel element composed of Zircaloy 2 covers and picture frame and a uranium$12 \mathrm{w} / \mathrm{o}$ molybdenum core.

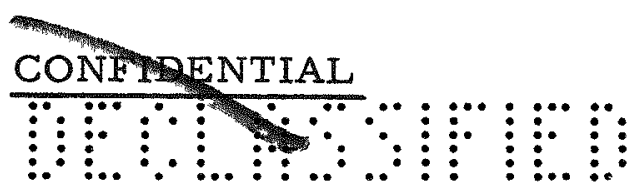




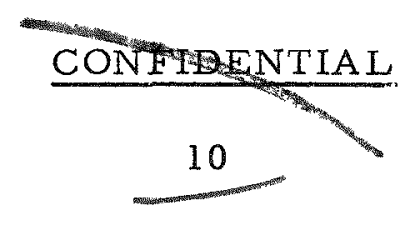

\section{PRESSURE-BONDING TECHNIQUES}

All pressure-bonding work was conducted in an evacuated chamber. The pressure was applied by a hydraulically operated ram transmitting the force through a bellows to a die ram. This force was further transmitted by the die ram, resulting in pressure on the top and bottom of the specimen. If a tapered ram and die were not feasible for a certain set of bonding conditions, side pressure was exerted by use of a die material with a low thermal-expansion coefficient or by use of a material with a high coefficient of expansion adjacent to the specimen and retaining yoke with a low coefficient of the rmal expansion.

\section{Pressure-Bonding Equipment}

A 75-ton air-hydraulic press and a 100-ton hand-pumped press were used to apply pressure during bonding. Unless creep or plastic flow of the die rams occurred, pressures could be held at temperature for 18-hr intervals.

The most difficult problem encountered in producing bonded specimens was the design of dies and rams with suitable strength and creep properties to produce the desired combination of bonding conditions. In some instances die life was relatively short. Four types of die materials were used in an effort to bond over a temperature range of 975 to $1650 \mathrm{~F}$ (see Table 1 ).

TABLE 1. DIES FOR PRESSURE BONDING

\begin{tabular}{|c|c|c|c|c|c|}
\hline \multirow[b]{2}{*}{ Die Material } & \multirow[b]{2}{*}{ Yoke Material } & \multicolumn{3}{|c|}{ Temperature } & \multirow[b]{2}{*}{$\begin{array}{c}\text { Taper, } \\
\text { deg }\end{array}$} \\
\hline & & $\begin{array}{l}\text { Pressure Range, } \\
\text { psi }\end{array}$ & $\begin{array}{c}\text { Range, } \\
\text { F }\end{array}$ & Insert & \\
\hline 304 sta inless steel & SAE 1020 & $5,000-10,000$ & $975-1050$ & None & 5 \\
\hline Carpenter 883 & SAE 1020 & $5,000-20,000$ & $1050-1200$ & Carpenter 883 & 7 \\
\hline Molybdenum & 316 stainless steel & $2,000-20,000$ & $1150-1350$ & 347 sta inless steel & 2 \\
\hline Graphite & None & $600-1,000$ & $1350-1650$ & None & 7 \\
\hline Graphite & None & $600-1,000$ & $1450-1650$ & None & None \\
\hline
\end{tabular}

In general, sufficient side pressure was obtained at the higher temperatures with carefully fitted specimens in graphite dies without using tapered dies and rams. 


\section{CONANDENTAL}

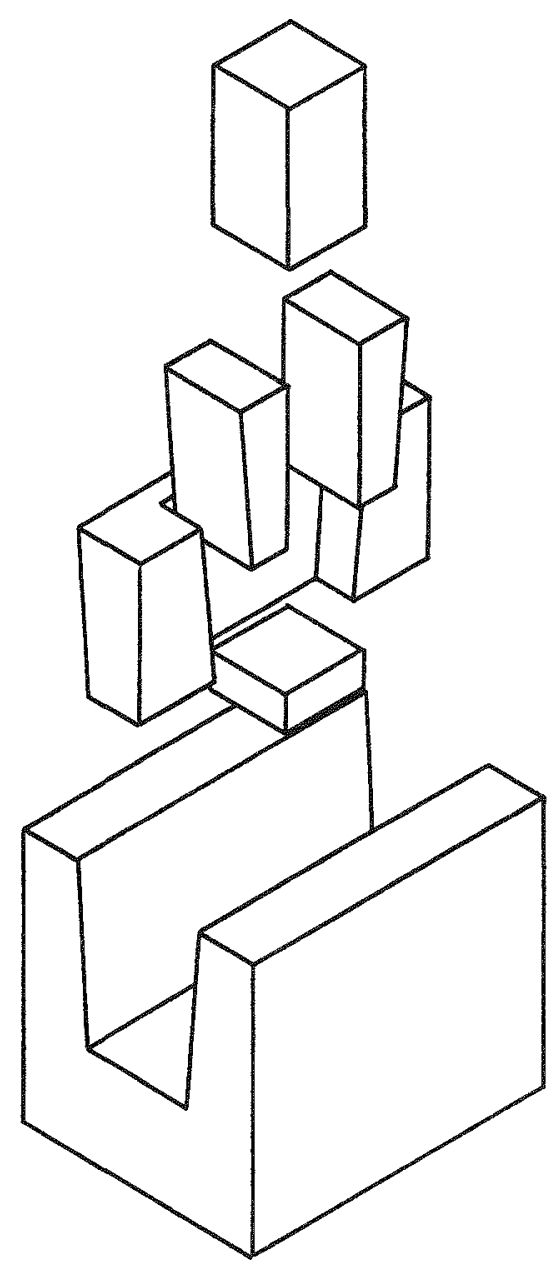

$0.5 \mathrm{X}$

N23125

FIGURE 2. SPLIT-TYPE DIE

Carpenter 883 stainless steel rams and inserts with a mild-steel retaining yoke. 


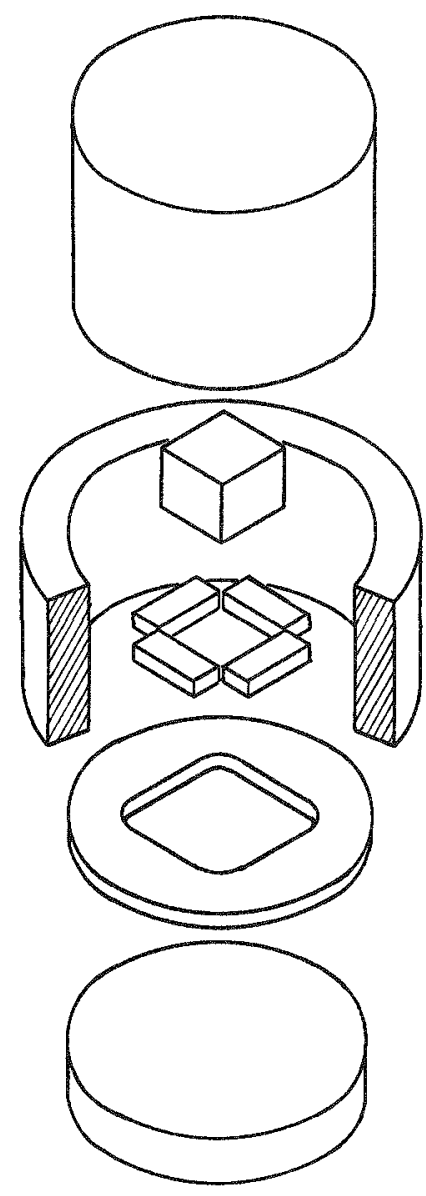

$0.5 \mathrm{X}$

N23126

FIGURE 3. MOL YBDENUM-RING-INSER T DIE

Die composed of 316 stainless steel yoke, 347 stainless steel spacers, and 316 stainless steel top and bottom rams with a molybdenuminsert $r$ ing. 

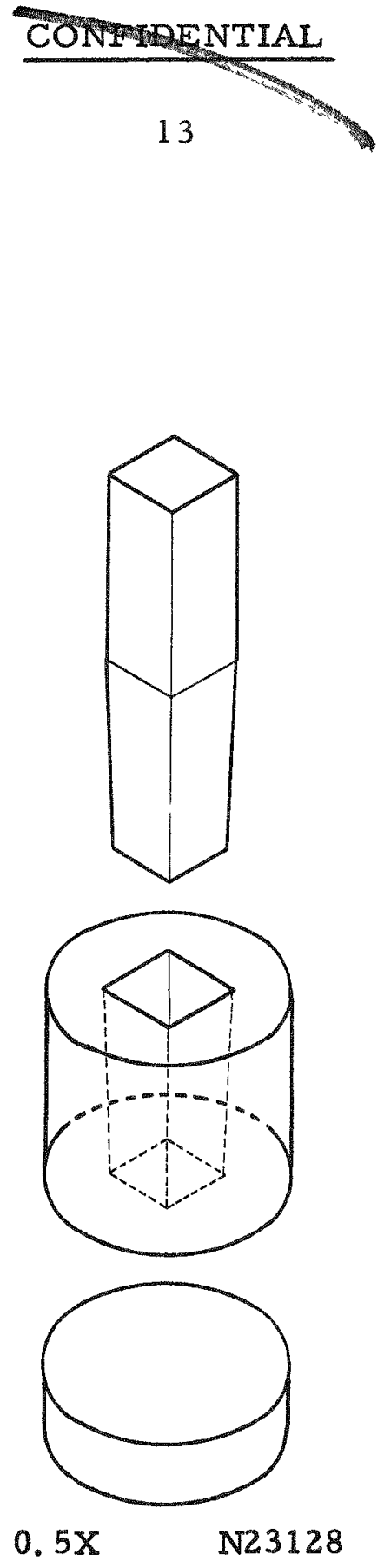

FIGURE 4. HIGH-TEMPERATURE DIE

Ram and die cavity tapered.

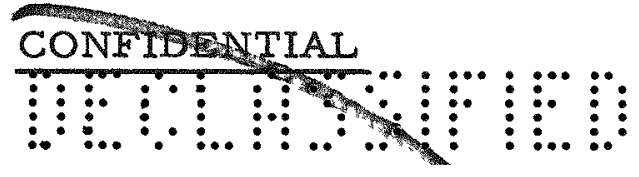




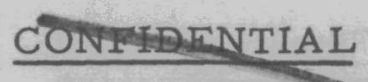

14

Drawings of some of the dies used in this study are illustrated in Figures 2, 3, and 4 .

\section{EFFECT OF INTERDIFFUSION ON THE CORROSION PROPERTIES OF THE INTERFACE}

The coextrusion cladding process generally produces bonding with a minimum amount of interdiffusion. However, it is anticipated that slight variations of interdiffusion will occur. Such variations could result in erratic behavior during cladding failure and exposure of the interface to high-temperature water. This portion of the investigation was conducted to determine the effects of interdiffusion on the corrosion properties of the interface.

In the initial phase of the investigation specimens were prepared with a mechanical bond between the Zircaloy 2 and uranium-12 w/o molybdenum alloy. This was done to find if a metallurgical bond was necessary. The test specimens, clad at low temperatures, were defected with a 40-mil hole penetrating to the center of the core. The Zircaloy 2 covers blistered and separated during corrosion testing in water at $650 \mathrm{~F}$. It is conceivable that a failure of this type would not be readily observed in a rod-type element; however, in operation such a failure would be expected to produce a hot spot with subsequent rupture of the cladding-tube wall. A typical mechanical bond is illustrated in Figure 5 .

Core alloy

Zircaloy 2

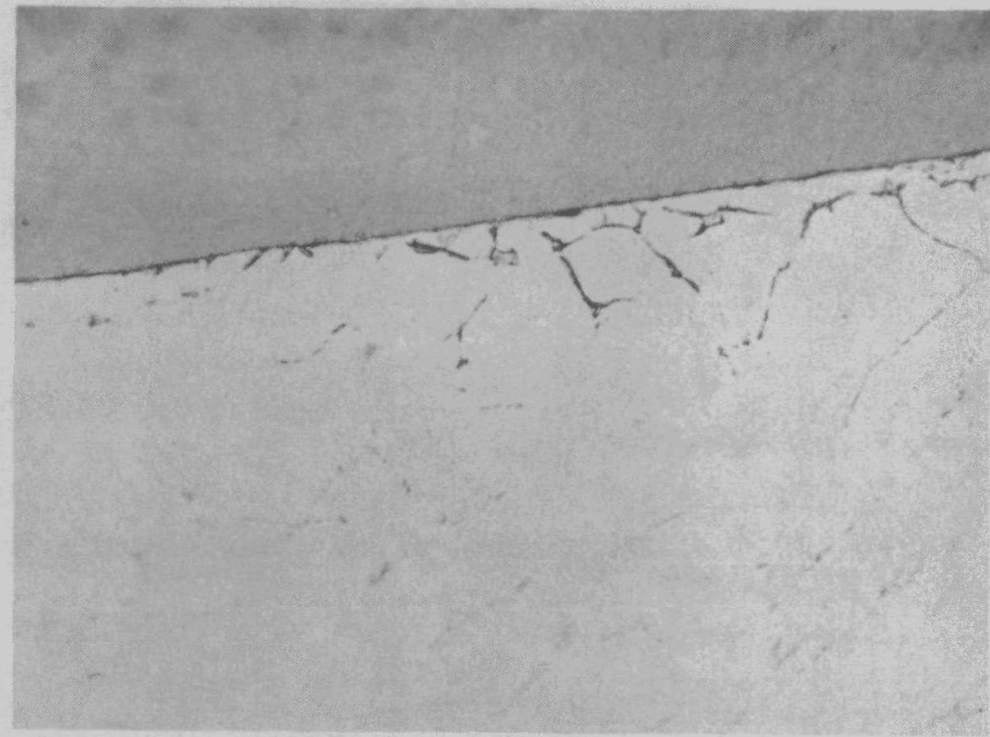




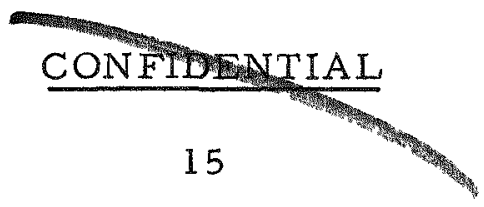

A large number of metallurgically bonded specimens were prepared with varying degrees of diffusion. The specimens were bonded at pressures ranging from 600 to $40,000 \mathrm{psi}$, temperatures of 975 to $1600 \mathrm{~F}$, and time intervals of $2 \mathrm{sec}$ to $24 \mathrm{hr}$.

For each set of bonding conditions, two clad specimens were prepared; one to test in corrosion, and the other to examine for bond characteristics such as diffusion zone, strength, and continuity. In addition, bare specimens were subjected to the same heat treatments as the bonded specimens and tested to evaluate the effect of the bonding treatments on the corrosion properties of the base core alloy.

Diffusion interfaces ranging from those with a very minimum amount of interdiffusion to 6 mils were produced during pressure bonding of the specimens. Except in the cases of minimum and maximum diffusion, interfaces were formed with alloy layers exhibiting good continuity. Strength of the bonds was qualitatively determined by peel tests and cold rolling of the bonded specimens. In general, the bonds withstood a 10 per cent cold reduction by rolling; however, most cold reductions of 20 per cent resulted in failure of the interface along the alloy layers adjacent to the core. Specimens reduced 10 per cent are shown in Figures 6, 7, and 8 . These figures also illustrate various degrees of diffusion at the bond interfaces.

All of the specimens which were tested developed blisters or failed after 72 to $168 \mathrm{hr}$ of exposure to high-temperature water. The specimens that required $168 \mathrm{hr}$ of testing before failure occurred were generally those with minimum diffusion bonds. The coextruded specimens prepared and tested by WAPD normally tested for much longer periods before failure occurred. Evidently a minimum amount of diffusion is the most suitable condition for optimum corrosion resistance.

Typical pressure-bonded specimens are shown in Figures $9,10,11$, and 12. A range of diffusion interfaces can be observed in this series of photomicrographs. As-failed samples are illustrated in Figures 13, 14 , 15 , and 16.

Figures 17 and 18 illustrate coextruded bonds. A minimum amount of diffusion is encountered in this type of bond. The smearing action of core and clad obtained during the extrusion operation produces a strong interlocking bond.

Coextruded specimens, heat treated to produce extensive diffusion, were corrosion tested to verify the corrosion behavior encountered with the pressure-bonded samples. These specimens failed in the same manner as the pressure-bonded specimens. Figure 19 illustrates this type of failure.

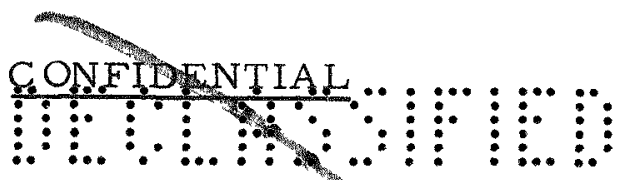




\section{CONFIDENTIAL}

16

Core alloy

Zircaloy 2

Core alloy

Zircaloy 2

Core alloy

Zircaloy 2
$500 \mathrm{X}$

N23846

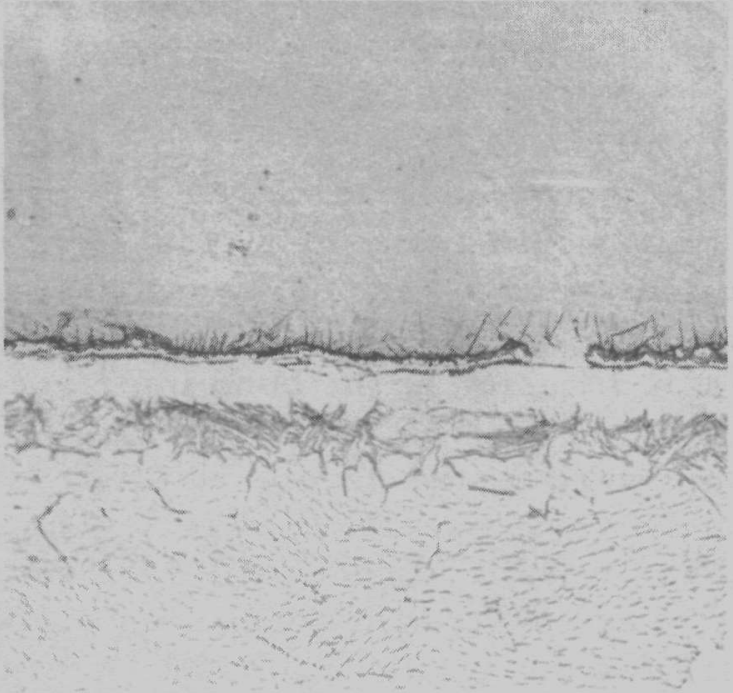

$500 \mathrm{X}$

N23847

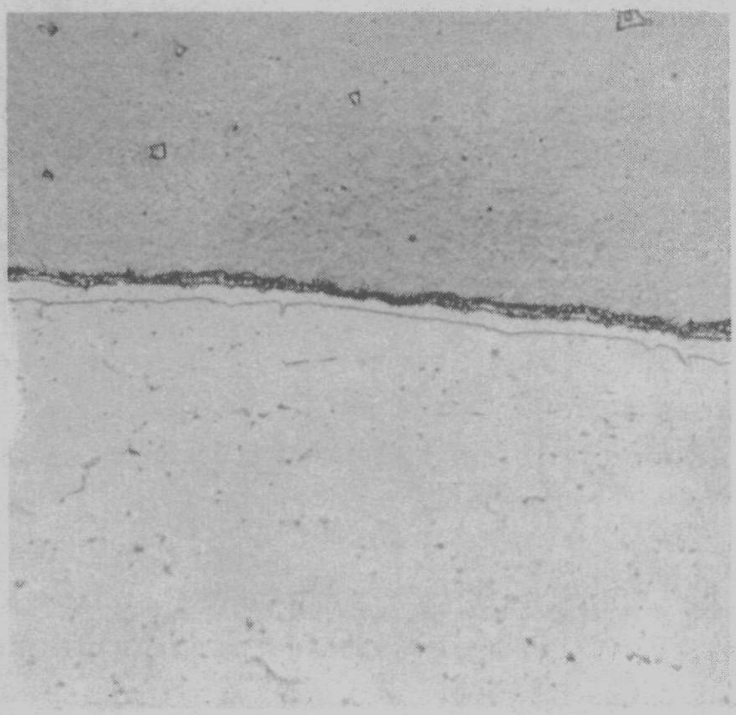

$500 \mathrm{X}$

N23848
FIGURE 6. BOND-STRENGTH TEST SPECIMEN BONDED AT $1200 \mathrm{~F}$ USING 12,000 PSI FOR 1/4 HR AND COLD REDUCED 10 PER CENT
FIGURE 7. BOND-STRENGTH TEST SPECIMEN BONDED AT $1400 \mathrm{~F}$ USING 600 PSI FOR $1 \mathrm{HR}$ AND COLD REDUCED 10 PER CENT
FIGURE 8. BOND-STRENGTH TEST SPECIMEN BONDED AT $1200 \mathrm{~F}$ USING 12,000 PSI FOR 1/4 HR AND COLD REDUCED 10 PER CENT 


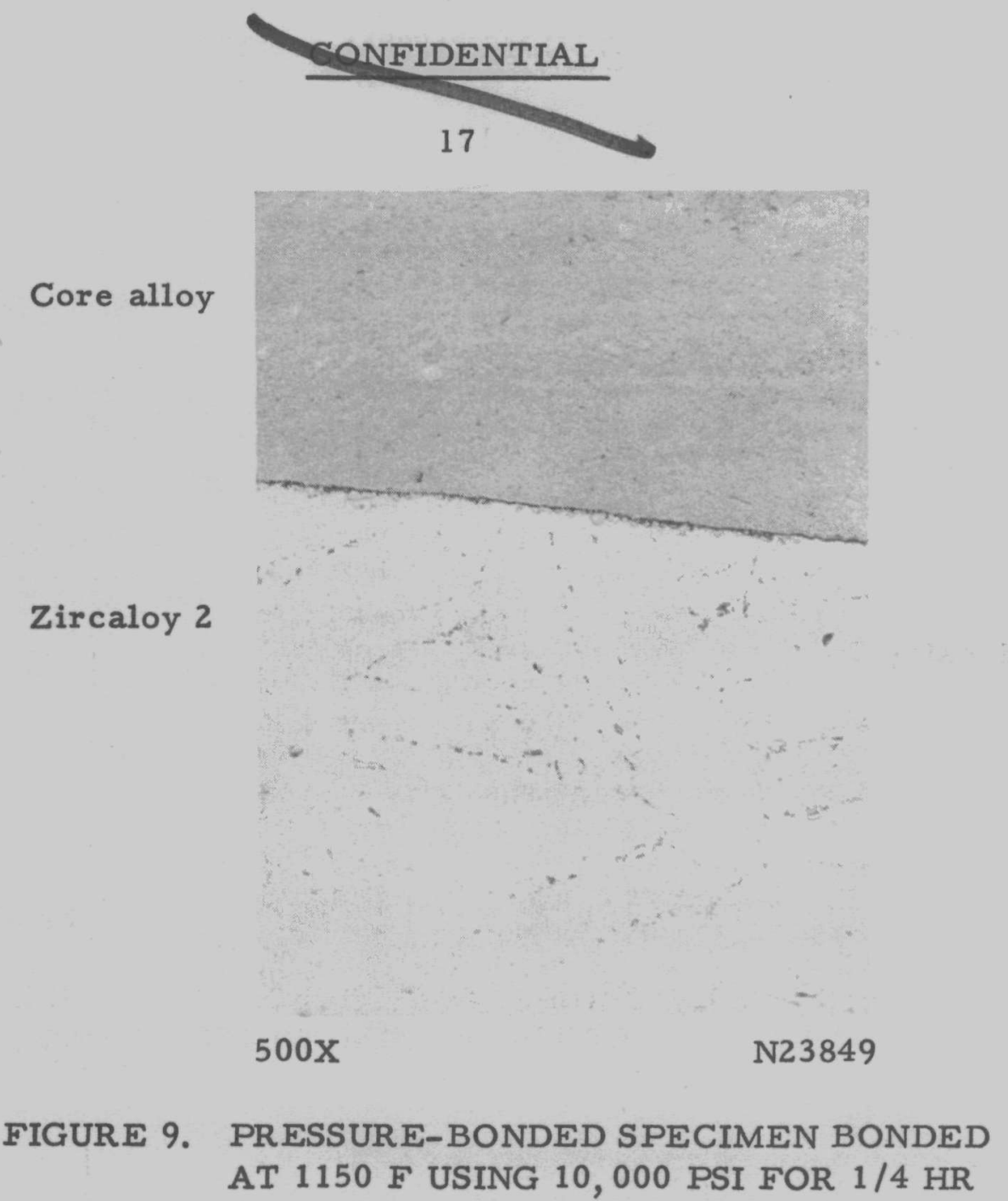

AT 1150 F USING 10,000 PSI FOR $1 / 4$ HR

Core alloy

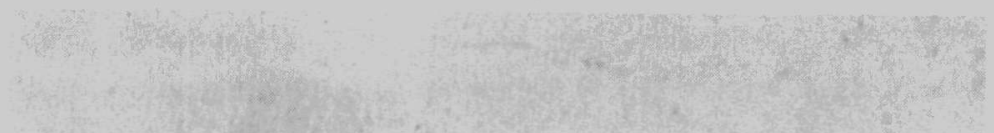

$500 x$

N23850

FIGURE 10. PRESSURE-BONDED SPECIMEN BONDED AT 1400 F USING 600 PSI FOR 3/4 HR

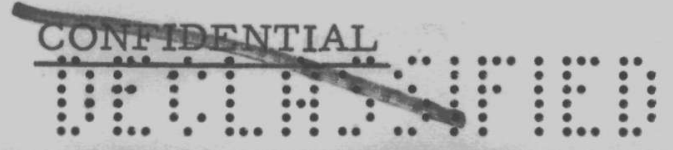


Core alloy

Zircaloy 2

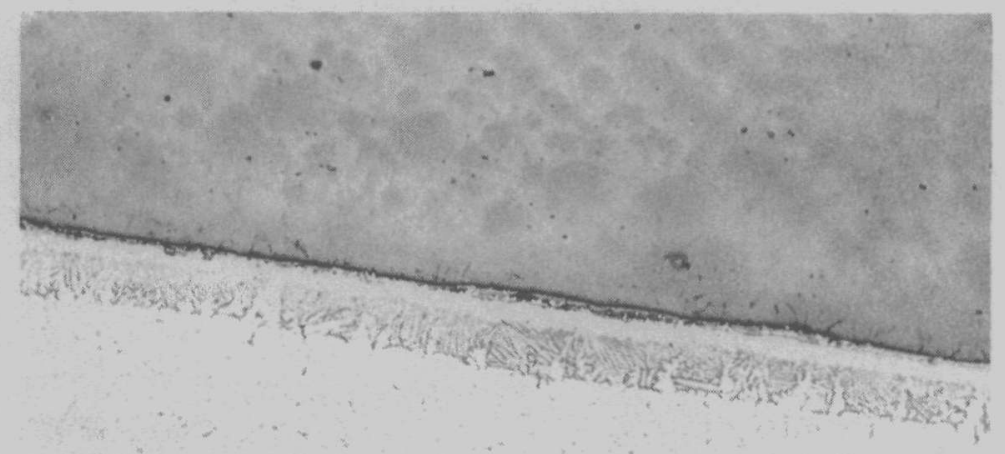

FIGURE 11. PRESSURE-BONDED SPECIMEN BONDED AT 1300 F USING 10,000 PSI FOR 2 HR

Core alloy

Zircaloy 2

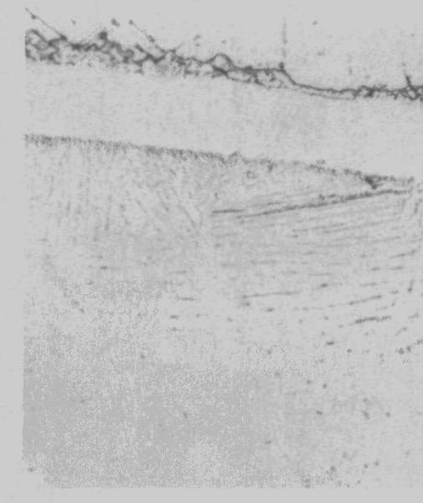

$250 \mathrm{x}$

N23852

FIGURE 12. PRESSURE-BONDED SPECIMEN BONDED AT 1400 F USING 600 PSI FOR 4 HR 
Core

Zircaloy 2

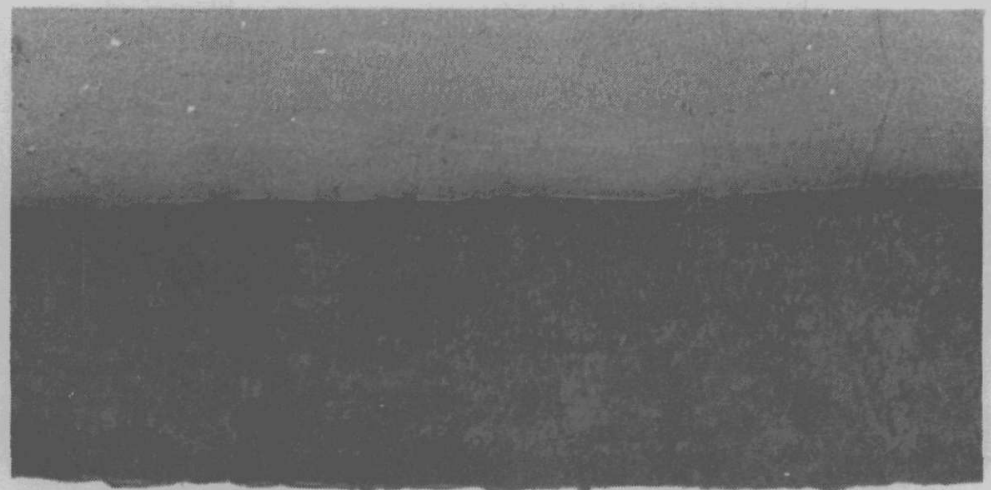

53rth

FIGURE 13. CORROSION-TESTED SPECIMEN TESTED 72 HR IN $650 \mathrm{~F}$ W ATER

Bonded at $1200 \mathrm{~F}$ using $10,000 \mathrm{psi}$ for $1 / 4 \mathrm{hr}$.

\section{Zircaloy 2} $500 \mathrm{X}$

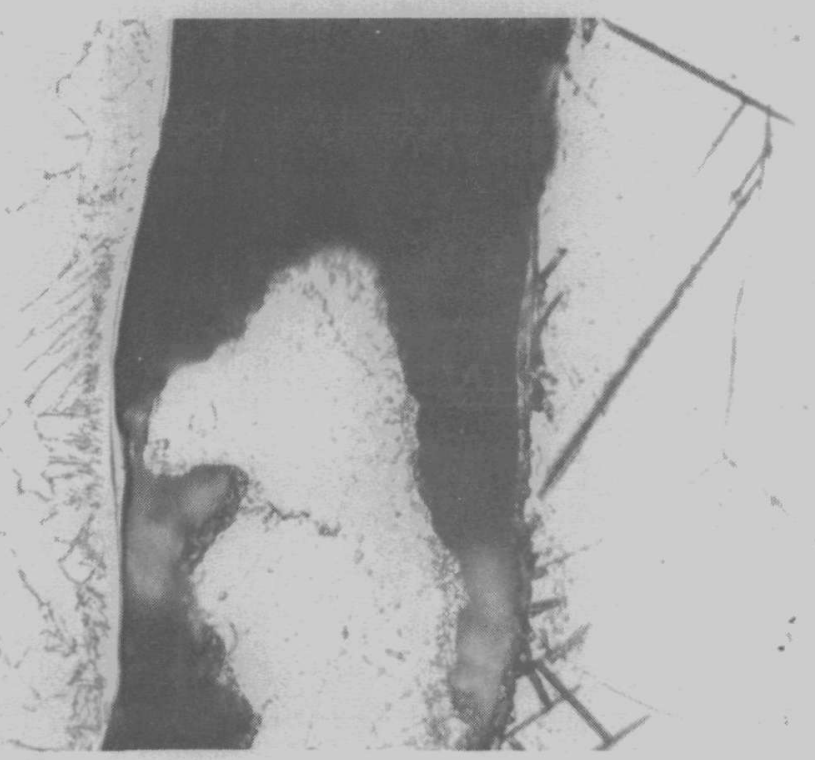

Core

N23854

FIGURE 14. CORROSION-TESTED SPECIMEN TESTED 168 HR IN 650 F WATER

Bonded at $1400 \mathrm{~F}$ using $20,000 \mathrm{psi}$ for $2 \mathrm{sec}$.

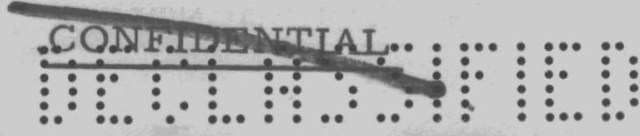


Core alloy

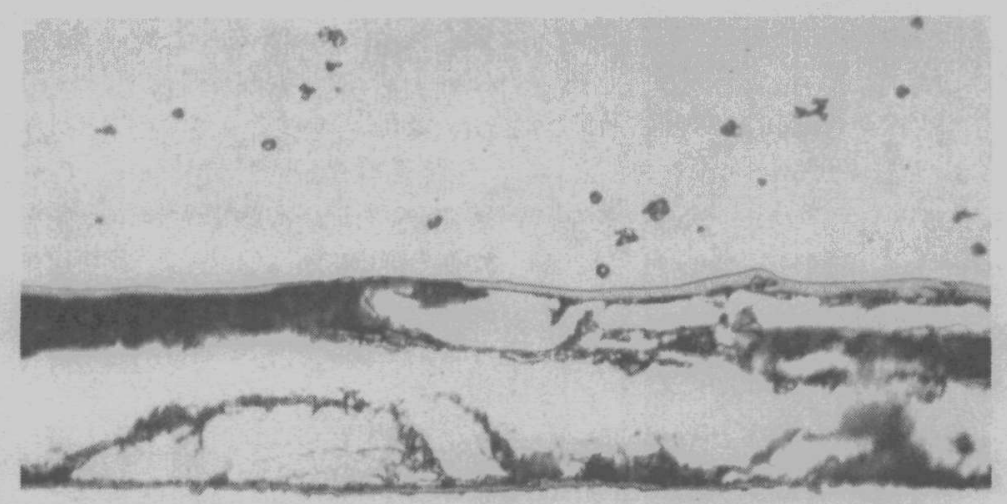

Zircaloy 2

$500 x$

N23855

FIGURE 15. CORROSION-TESTED SPECIMEN TESTED 72 HR IN 650 F WATER

Bonded at $1150 \mathrm{~F}$ using $10,000 \mathrm{psi}$ for $5 \mathrm{~min}$.

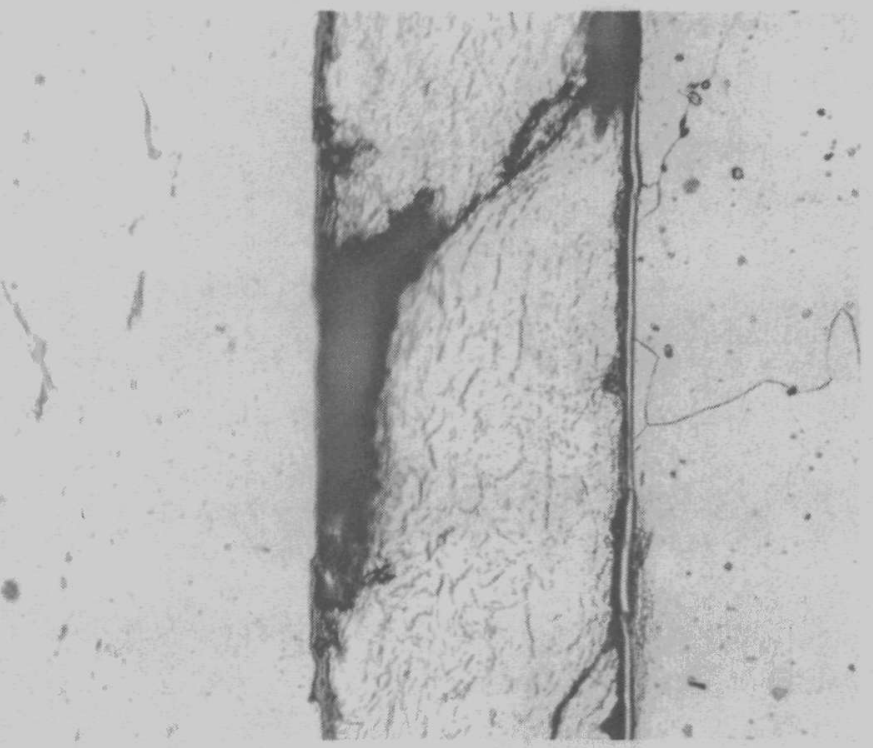

Zircaloy 2

Core alloy $500 x$ N23856

FIGURE 16. CORROSION-TEST SPECIMEN TESTED 168 HR IN 650 F WATER

Bonded at $1200 \mathrm{~F}$ using $20,000 \mathrm{psi}$ for $1 / 4 \mathrm{hr}$.

\section{GONARENTIAL}




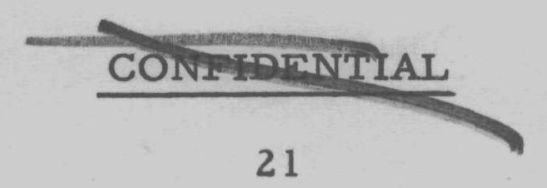

Core alloy

Zircaloy 2

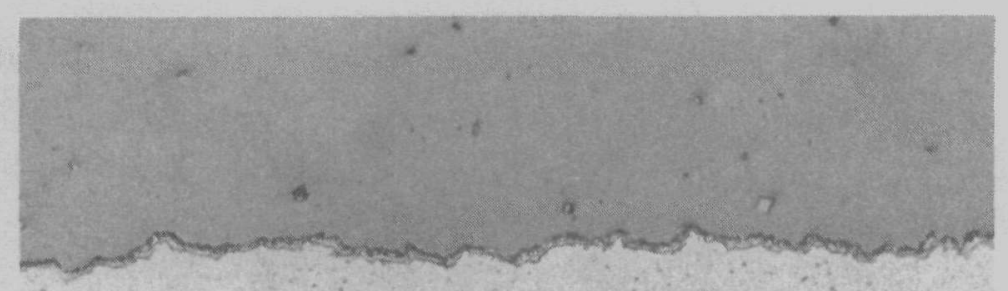

$500 \mathrm{x}$

N23857

FIGURE 17. EXTRUSION-CLAD BOND PRODUCED BY COEXTRUSION OF CORE AND CLADDING

Core alloy

Zircaloy 2

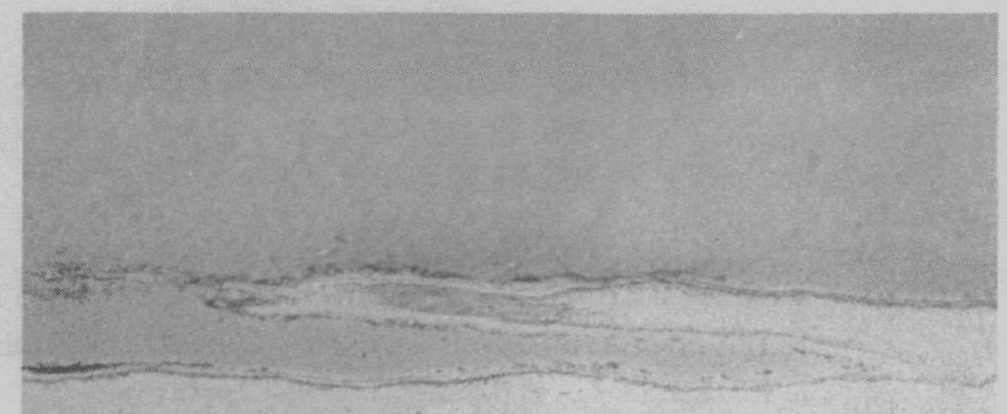

$500 \mathrm{x}$

N23858

FIGURE 18. EXTRUSION-CLAD BOND PRODUCED BY COEXTRUSION OF CORE AND CLADDING 


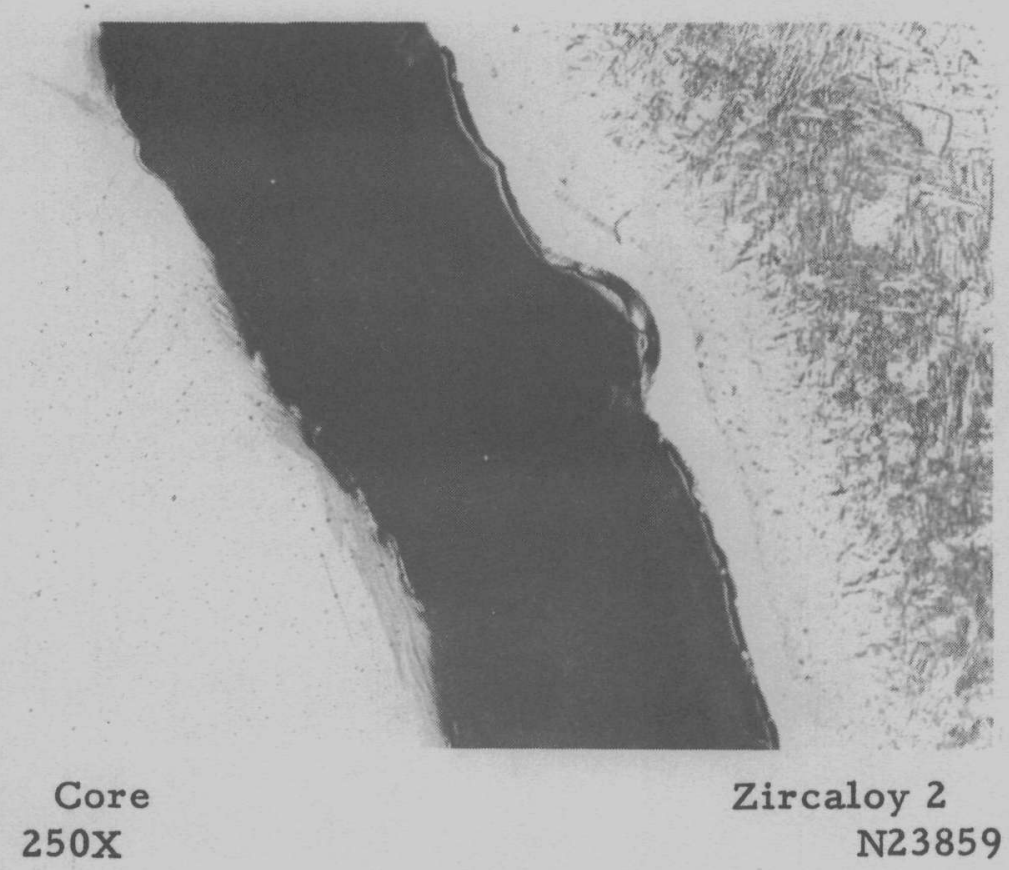

FIGURE 19. EXTRUSION-CLAD CORROSION-TEST SPECIMEN ANNEALED 2 HR AT 1800 F AND CORROSION TESTED 72 HR 


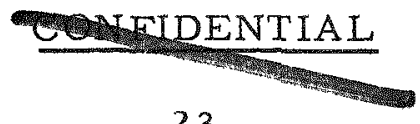

23

The persistent preferential attack of high-temperature water on certain alloy layers of the interface promoted interest in the identification of the alloy layer initially attacked and the composition of each of the phase layers in the interface.

Extrusion-clad specimens prepared by WAPD were subjected to various heat treatments to determine the effect of diffusion on the corrosion properties of the interface. A diffusion anneal of $1 / 4 \mathrm{hr}$ at $1800 \mathrm{~F}$ was sufficient to destroy the corrosion properties of the interface. The interface failed completely after $336 \mathrm{hr}$ of exposure to $650 \mathrm{~F}$ water. Similar specimens treated at $1800 \mathrm{~F}$ for longer periods and furnace cooled failed after $168 \mathrm{hr}$ of corrosion testing. Water or air quenching of specimens annealed at $1800 \mathrm{~F}$ failed to improve the corrosion properties of the interface.

It is extremely difficult to bond specimens by use of the pressurebonding technique and achieve the limited interdiffusion encountered in the coextrusion process. Apparently there was enough diffusion during bonding of all of the tested samples to produce phases possessing poor corrosion resistance.

Metallographic investigation of all of the as-failed corrosion specimens revealed preferential corrosion attack of the center portions of the diffusion zones. The same alloy-phase layers were attacked in each case. These layers were observed in almost every one of the pressure-bonded samples and in the heat-treated extrusion-clad specimens subjected to the $1800 \mathrm{~F}$ diffusion anneal.

\section{Nature of the Bond Interface}

The severe, rapid failure of the interface encountered during corrosion testing of the defected pressure-bonded specimens led to an extensive study of the bond interface. The purpose of this investigation was the determination of the mechanism of corrosion failure and identification of the alloy layers present in the bond interface.

In order to study the mechanism of corrosion, specimens were treated to form flush diffusion bonds which were amenable to metallographic study and analytical analysis. Cross sections of such specimens were corrosion tested for short intervals of time in order to detect the initiation of corrosion and its manner of attack. The specimens were examined by metallographic techniques to determine the alloy layers possessing the poorest corrosion resistance. Analytical samples were obtained from each layer across the interface to establish the composition of the various phases occurring in the interface. 
Both extrusion-clad and pressure-bonded specimens were annealed to accentuate the alloy layers of the bond interface prior to corrosion testing in high-temperature water. Corrosion was initiated in one of the alloy layers in approximately $1 / 4 \mathrm{hr}$. Advanced corrosion of the interface in these small specimens produced voids $0.005 \mathrm{in}$. wide after $2 \mathrm{hr}$ of testing.

Photomicrographs of a series of extrusion-clad and pressure-bonded specimens after varying exposures to $650 \mathrm{~F}$ water are shown in Figures 20 through 27. Initial attack can be observed in both the extrusion-clad and pressure-bonded specimens after 1/4 hr of exposure. A 2-hr exposure produced advanced corrosion attack on the interfaces of both types of specimens.

Metallographic examination of the interface after short- and longtime exposure to high-temperature water indicated the same alloy layers were attacked in all cases. The composition of these alloy layers was determined by analytical analysis and $\mathrm{X}-\mathrm{ray}$ examination.

A number of specimens were pressure bonded and subjected to a prolonged diffusion anneal to produce an extensive diffusion interface. The resulting specimens were examined for uniformity of alloy layers. Specimens with consistently uniform interface were carefully machined to obtain samples from each layer of the diffusion zone for spectrographic and chemical analyses.

Molybdenum, tin, and zirconium determinations were made by spectrographic analyses. The fluorescence method was used to analyze for uranium. Figure 28 illustrates the diffusion interfaces obtained in the two specimens used for determination of the composition of the layers. This specimen was annealed at $1800 \mathrm{~F}$ for $48 \mathrm{hr}$ to produce this extensive diffusion.

Layer 6 in Figure 28 and the angular phase contained in Layer 7 were determined by $\mathrm{X}$-ray techniques. The remaining determinations were made by chemical and spectrographic analyses.

The narrowest slit system available on the spectrometer was used to examine the interface by X-ray diffraction. Layer 6 was definitely identified as $\mathrm{ZrMO}_{2}$ and the angular phase embodied in Layer 7 was tentatively identified as $\mathrm{ZrC}$. The amount of $\mathrm{ZrC}$ formation obtained from the small amount of carbon available in the interface does not appear feasible but no other known binary compound fits the approximate reflection pattern obtained by $\mathrm{X}$-ray as well as $\mathrm{ZrC}$. The possibility of a ternary compound formation also exists. Layers 5 and 7 are body-centered-cubic. Layer 7 contains body-centered-cubic uranium-molybdenum, while Layer 5 contains some stabilized beta zirconium. The molybdenum content of Layer 5 is sufficient to product stabilized beta zirconium.

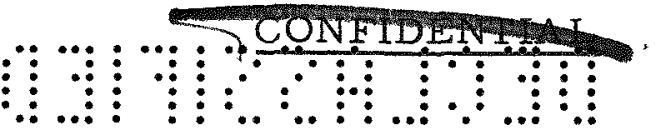




\section{CONFTDENTIAL}

Core alloy

Zircaloy 2

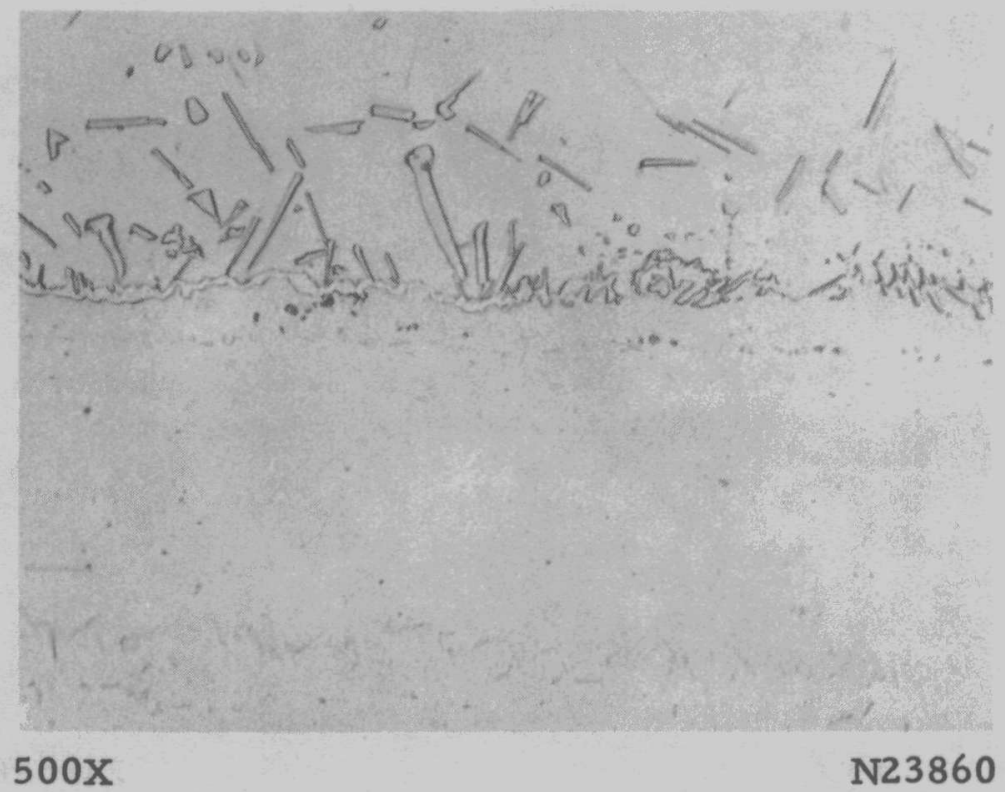

FIGURE 20. PRESSURE-BONDED SPECIMEN P-66

Core alloy

Zircaloy 2

Diffusion annealed for $36 \mathrm{hr}$ at $1800 \mathrm{~F}$, furnace cooled after bonding at $1400 \mathrm{~F}$, using $600 \mathrm{psi}$ for $1 \mathrm{hr}$.

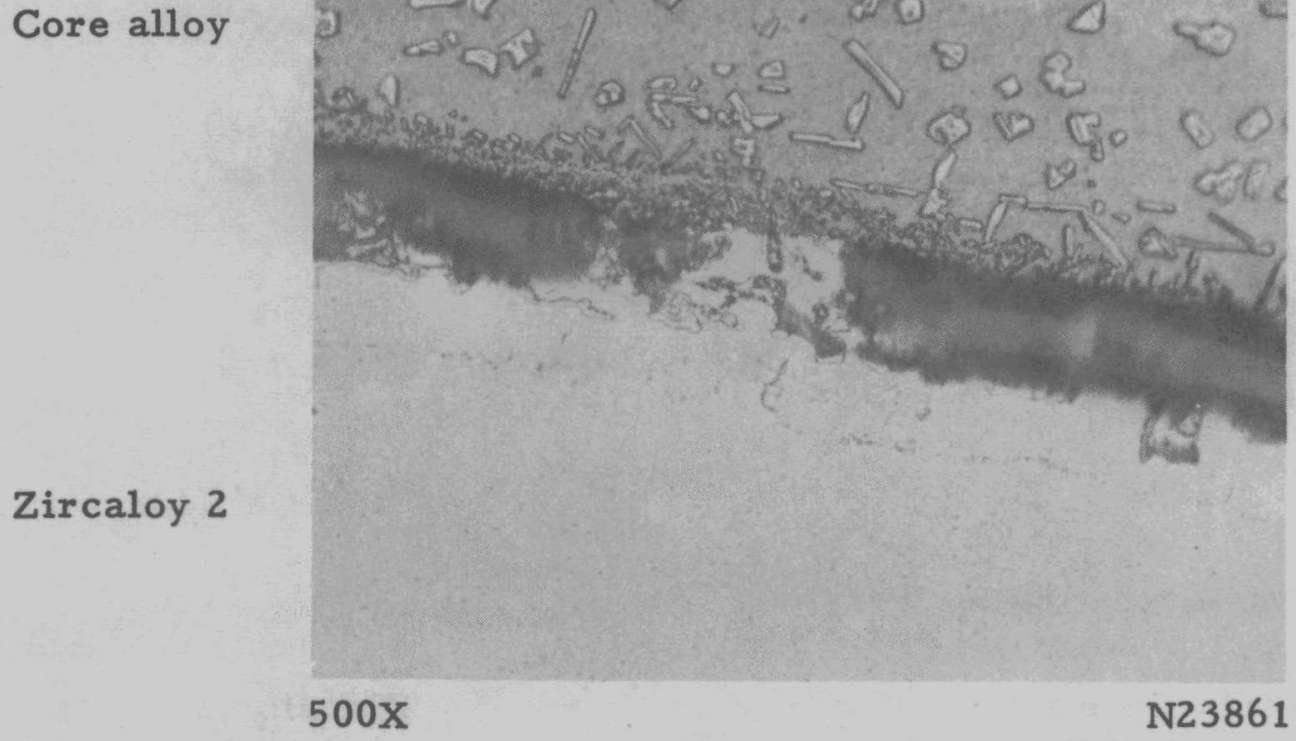

FIGURE 21. PRESSURE-BONDED SPECIMEN P-66 AFTER $1 / 2$ HR IN 650 F W ATER 


\section{CONFTDENTIAL}

26
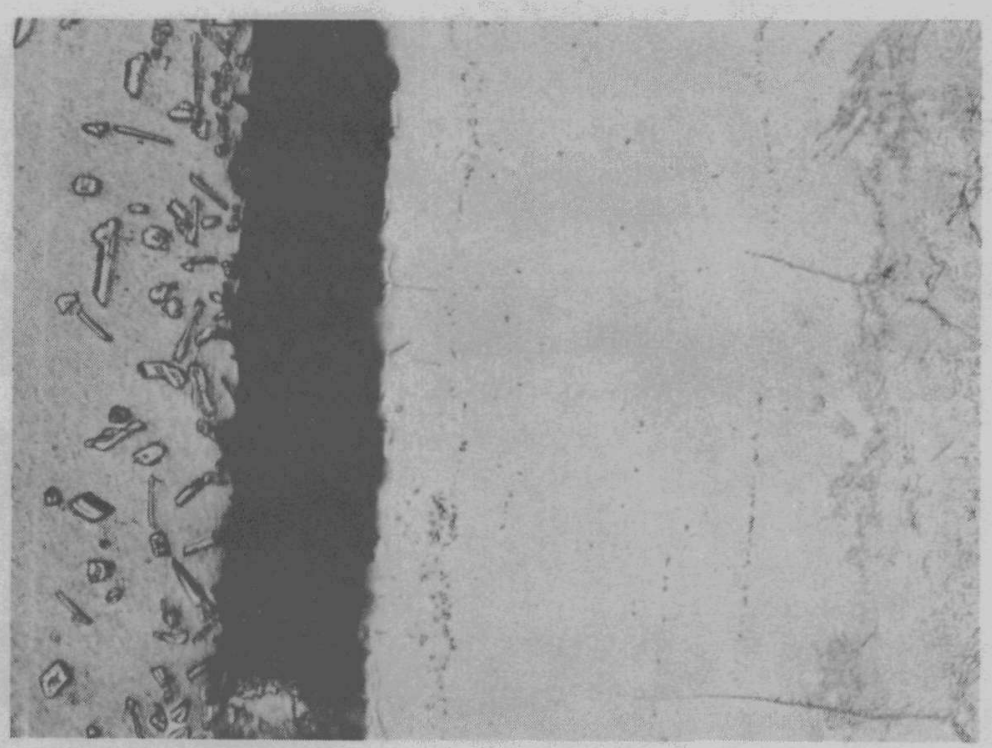

Core alloy

Zircaloy 2

$500 \mathrm{x}$

N23862

FIGURE 22. PRESSURE-BONDED SPECIMEN P-66 AFTER 1-1/2 HR IN 650 F WATER

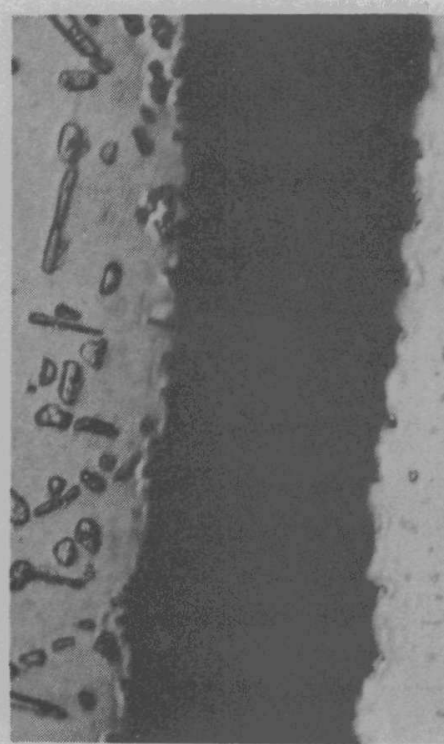

Core alloy $500 \mathrm{x}$

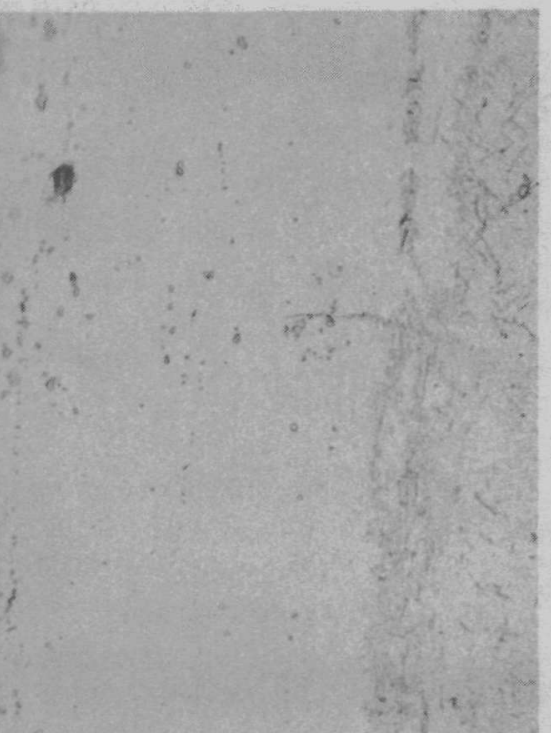

Zircaloy 2

N23863

FIGURE 23. PRESSURE-BONDED SPECIMEN P-66 AFTER 2 HR IN 650 F WATER

$\because \cdots:$ : $\cdots:$ : CONFIDANTIAL

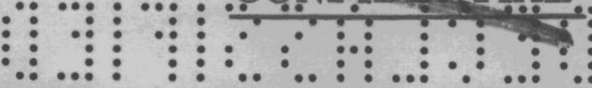




\section{CONFIDENTIAL}

\section{7}

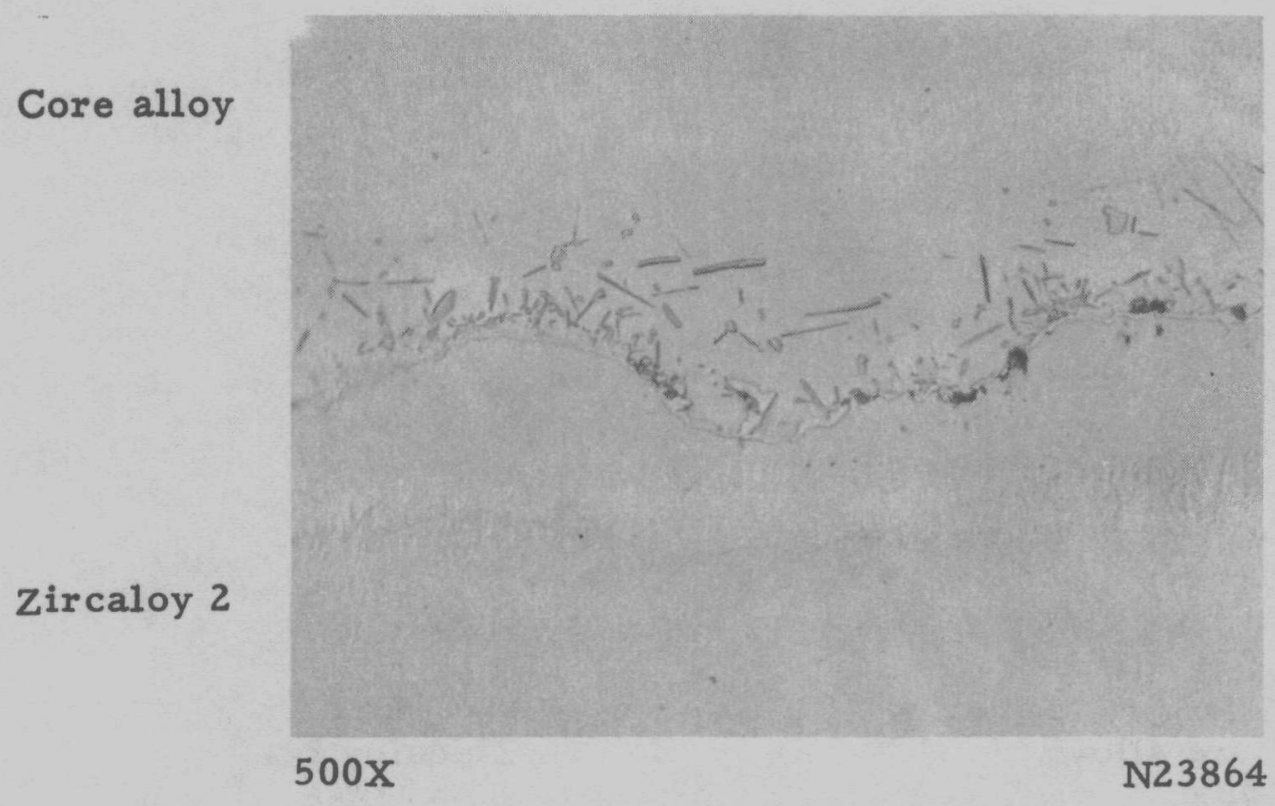

FIGURE 24. EXTRUSION-CLAD SPECIMEN CO-2E

Diffusion annealed for $4 \mathrm{hr}$ at $1800 \mathrm{~F}$ and furnace cooled.

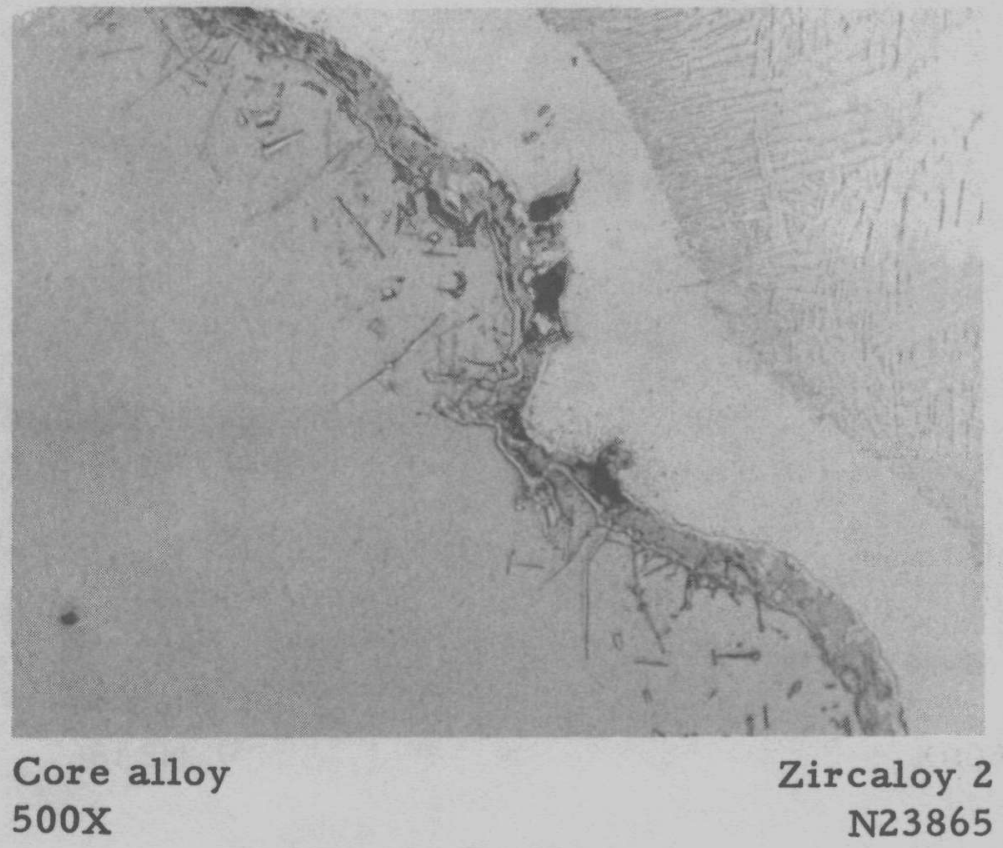

FIGURE 25. EXTRUSION-CLAD SPECIMEN CO-2E AFTER DIFFUSION ANNEAL AND 3/4 HR IN 650 F WATER

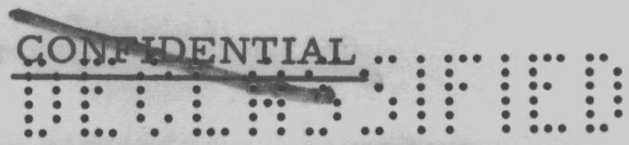




\section{CONFIDENTIAL}

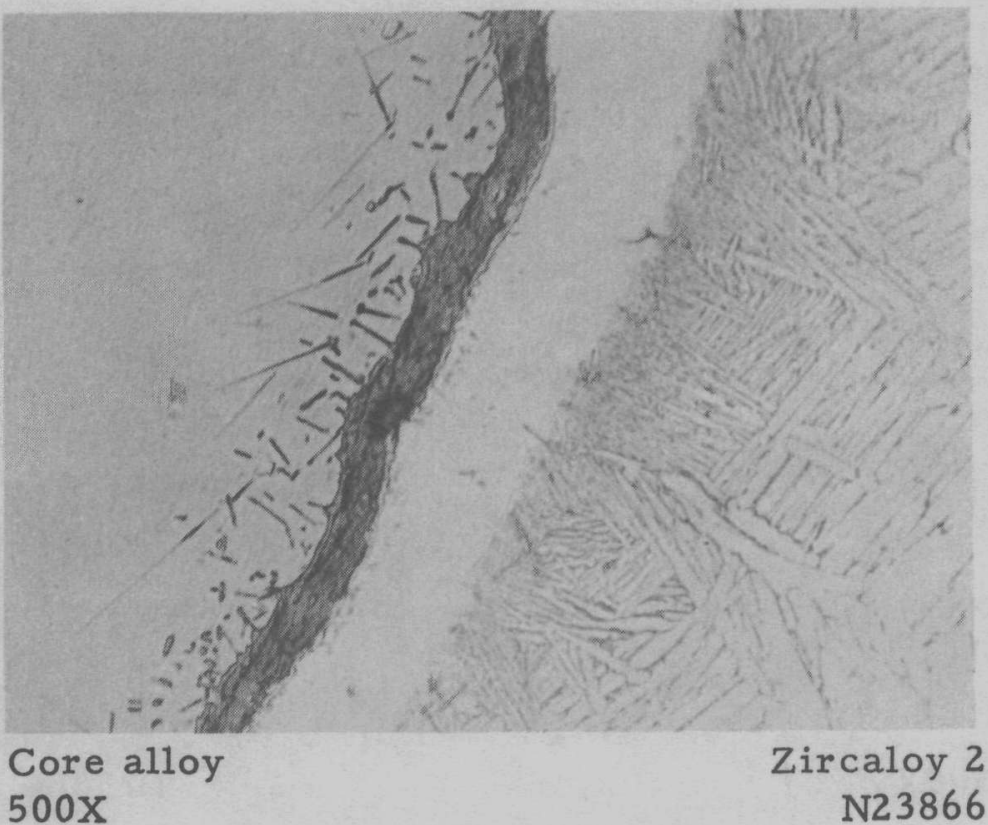

FIGURE 26. EXTRUSION-CLAD SPECIMEN CO-2E AFTER DIFFUSION ANNEAL AND 3/4 HR IN 650 F WATER

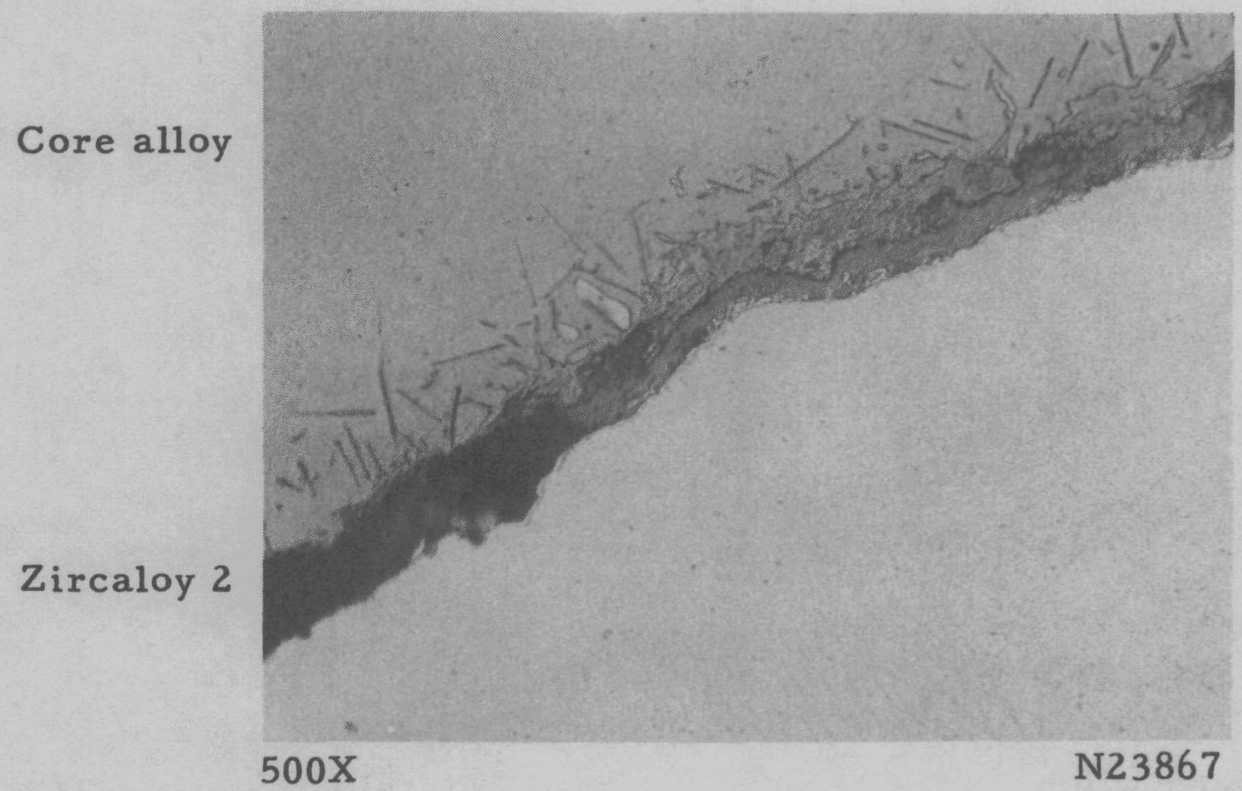

FIGURE 27. EXTRUSION-CLAD SPECIMEN Co-2E AFTER DIFFUSION ANNEAL AND 2-HR EXPOSURE TO 650 F WATER

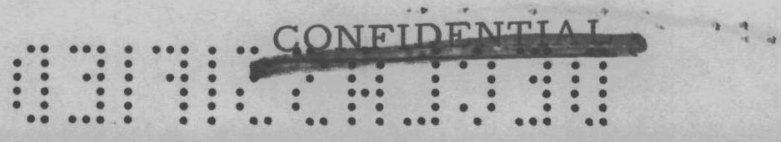




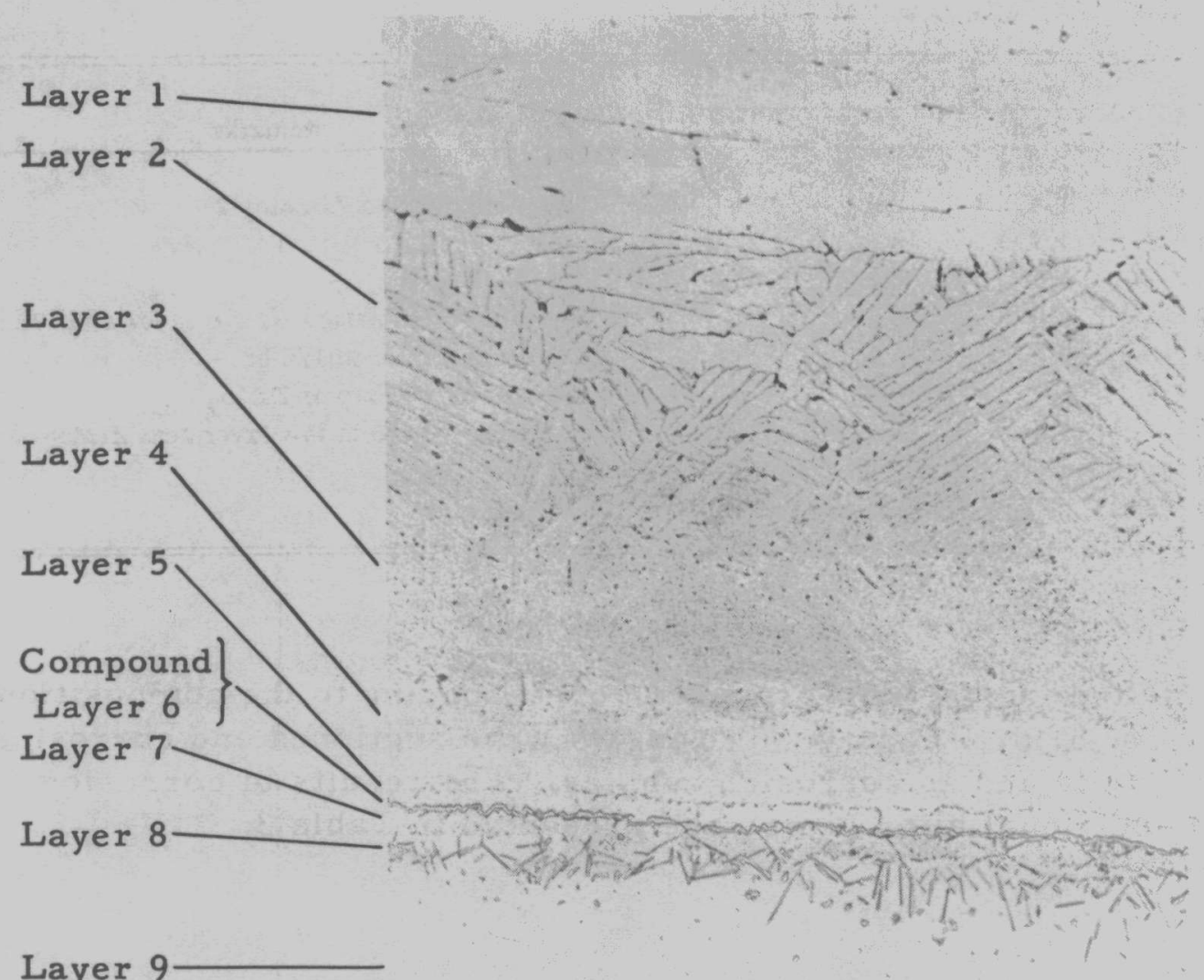

FIGURE 28. ALLOY LAYERS PRESENT IN INTERFACE OF A SPECIMEN PRESSURE BONDED AT 1400 F USING 600 PSI FOR 4 HR AND DIFFUSION ANNEALED FOR 48 HR AT $1800 \mathrm{~F}$ 
Table 2 contains the analysis of each layer as designated in Figure 28. The results of the spectrographic and chemical analyses are accurate to \pm 10 per cent of the amount reported.

TABLE 2. ANALYSES OF LAYERS PRESENT IN THE INTERFACE FORMED BETWEEN ZIRCALOY 2 AND URANIUM-12 W/O MOL YBDENUM

\begin{tabular}{|c|c|c|c|c|c|}
\hline \multirow[b]{2}{*}{ Layer } & \multicolumn{4}{|c|}{ Analysis, w/o } & \multirow[b]{2}{*}{ Remarks } \\
\hline & Mo & $\mathrm{Sn}$ & $\mathrm{U}$ & $\mathrm{Zr}$ & \\
\hline 1 & 0.15 & 1.45 & 2.1 & 94.0 & Layer adjacent to Zircaloy 2 \\
\hline 2 & 3.1 & 1.3 & 18.6 & 84.0 & \\
\hline 3 & 7.4 & 0.65 & 45.8 & 43.0 & \\
\hline 4 & 9.2 & 0.5 & 59.1 & 35.0 & Some corrosion attack on this layer after $72 \mathrm{hr}$ \\
\hline 5 & 12.3 & $<0.5$ & 78.0 & 18.0 & Corrosion failure in $1 / 2 \mathrm{hr}$ \\
\hline 6 & $-\infty$ & -- & $-\infty$ & $-\infty$ & Identified by $\mathrm{X}$-ray as $\mathrm{ZrMo}_{2}$ \\
\hline 7 & 12.5 & $<0.5$ & 85.3 & 1.5 & Corrosion failure in this layer near $\mathrm{ZrMo}_{2}$ layer \\
\hline 8 & 12.8 & $<0.5$ & 85.3 & 1.5 & \\
\hline 9 & 12.3 & - & 89.0 & - & Core alloy \\
\hline
\end{tabular}

Arc-melted ingots were prepared corresponding to the compositions of Layers 1, 4, 5, 6, 7, and 9. The ingots were sectioned and corrosion tested individually and as corrosion couples. The results of corrosion tests on the individual alloy layers are presented in Table 3.

TABLE 3. CORROSION RESISTANCE OF INTERFACE LAYERS

\begin{tabular}{cl}
\hline Layer & Corrosion Results After 24 Hr in 650 F Water \\
\hline 3 & Good \\
4 & Cracked, pitted, and warped \\
5 & Disintegrated \\
6 & Good except for a ppearance of cracks \\
7 & Good \\
\hline
\end{tabular}

As shown in Table 3, Layer 5, with a molybdenum content as high as the original core material, completely disintegrated in $24 \mathrm{hr}$. The rapid rate at which corrosion was observed to occur explains the wide voids obtained in the interface after a $72-\mathrm{hr}$ exposure to high-temperature water.

An attempt was made to determine if the corrosion attack on the interface was electrochemical in character. Sections were taken from the 
arc-melted alloy layers and welded together at one edge to form corrosion couples. The results obtained on these corrosion couples after a $24-\mathrm{hr}$ exposure to $650 \mathrm{~F}$ water are shown in Table 4. These results correlate with data obtained on bonded specimens.

TABLE 4. CORROSION RESISTANCE OF COUPLES

\begin{tabular}{ll}
\hline Composition of Couple & Results of 24-Hr Test in 650 F Water \\
\hline Layers 1 and 6 & No corrosion attack observed \\
Layers 1 and 9 & No corrosion attack observed \\
Layers 4 and 5 & Layer 4 cracked, Layer 5 disintegrated \\
Layers 4 and 6 & Layer 4 disintegrated, Layer 6 chipped \\
Layers 4 and 7 & Layer 4 cracked, Layer 7 good \\
Layers 5 and 6 & Layer 5 disintegrated, Layer 6 chipped \\
Layers 5 and 7 & Layer 5 disintegrated, Layer 7 good \\
Layers 6 and 7 & Layer 6 cracked, Layer 7 good \\
\hline
\end{tabular}

The arc-melted specimen of $\mathrm{ZrMo}_{2}$ was corrosion tested for a longer period than Layers 4, 5, and 7. The specimen, except for cracking, possessed corrosion resistance equivalent to the uranium-12 w/o molybdenum core alloy. This compound is relatively hard (VHN 750) and extremely brittle. The compound in the annealed condition is illustrated in Figure 29.

Metallographic samples were taken from ingots of Layers 4 and 5 and examined for structure. The alloys are in the as-arc-melted condition and are illustrated in Figures 30 and 31. The structure in both cases appears to be retained gamma.

All of the layers of the interface formed between cladding and core have been tentatively identified by X-ray or chemical analysis. The corrosion properties of the alloy layers of this interface were studied in detail with short-time corrosion tests. The layers most susceptible to corrosion attack were tested individually and as corrosion couples. Results obtained from these tests served to verify the poor corrosion properties of interfaces embodying these layers.

Efforts to eliminate the anomalous corrosion behavior of the interface were made through the use of transition bonding layers. 


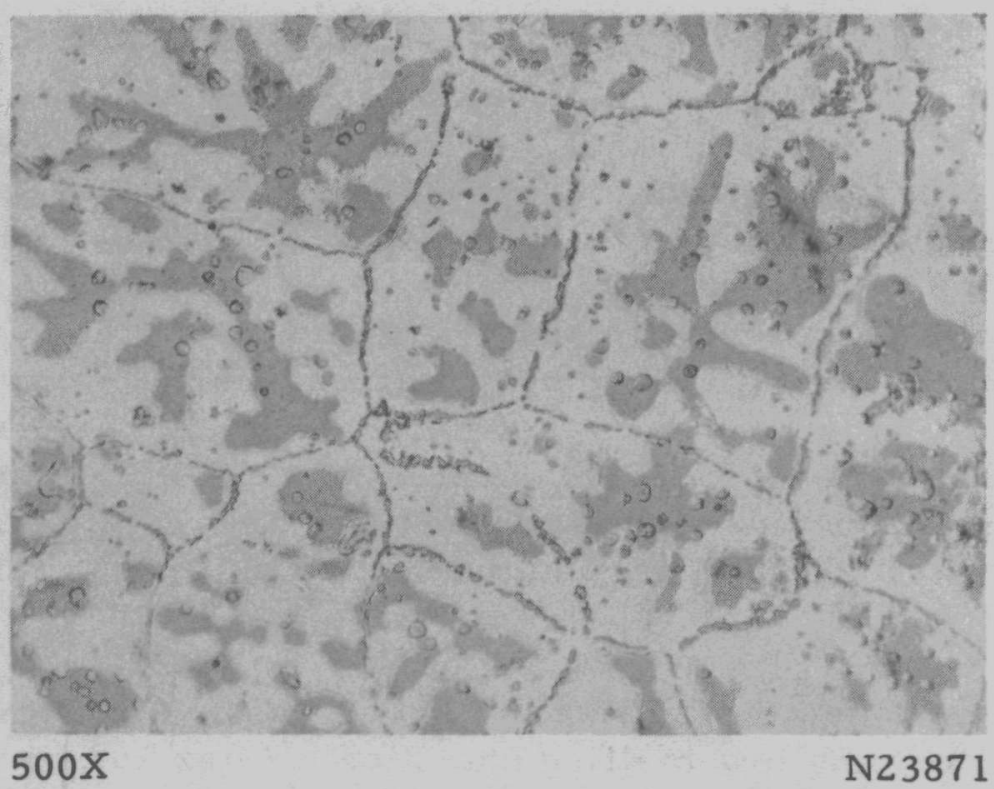

FIGURE 31. LAYER 5 OF ZIRCALOY 2-CLAD URANIUM-12 w/o MOLYBDENUM CORE ALLOY IN THE AS-ARCMELTED CONDITION 
TRANSITION BONDING LAYERS

Intermediate Layers Between Zircaloy 2 and

Uranium-12 w/o Molybdenum

Transition bonding layers were investigated in an effort to produce a more corrosion-resistant bond than could be obtained by direct bonding of the core to the cladding.

Available corrosion data on clad specimens indicated that any transition bonding layer which would be effective in preventing absorption of hydrogen by the base alloy would probably improve the corrosion resistance of the specimen. Since zirconium is a strong hydrogen getter, such a layer would need to be more effective than the Zircaloy 2.

Transition layers were effected by electroplating the core or by placing foil between the core and cladding. Elements forming low-temperature eutectics, as well as those possessing solubility in the gamma phase, were investigated. The cores were electroplated with a $0.001-$ in. coat of chromium, iron, or nickel. Foil was used to study the effects of transition layers of molybdenum, niobium, platinum tantalum, and uranium-10 w/o niobium.

Electroplated layers of chromium produced the most favorable results of the elements forming low-melting eutectics. After $168 \mathrm{hr}$ of testing, the samples prepared with a chromium transition layer showed a high rate of attack, but had not failed completely. The iron and nickel specimens completely failed after $72 \mathrm{hr}$ of testing. Figures 32 and 33 show the as-bonded and as-failed nickel-transition-layer specimen. Figures 34 and 35 illustrate chromium and iron in the as-failed condition.

An intermediate layer of 0,005-in. molybdenum foil was used to establish a sound metallurgical bond between core and cladding. Strong bonds were achieved by bonding at $1400 \mathrm{~F}$ using $600 \mathrm{psi}$ for $4 \mathrm{hr}$. The asbonded specimen is shown in Figure 36. Another specimen bonded under similar conditions is shown in Figure 37 after $72 \mathrm{hr}$ in high-temperature water.

Niobium sheet was cold rolled to $0.002-i n$. foil to provide material for use as a transition layer. Bonding of core and cladding to the niobium intermediate layer was effected at $1400 \mathrm{~F}$, using 2000 psi for $5 \mathrm{sec}$. A short time at pressure and temperature was used in an effort to minimize the interdiffusion of core and niobium, since extensive diffusion had occurred in earlier specimens held at temperature and pressure for $1 \mathrm{hr}$. This specimen is exhibited in the as-failed condition in Figure 38 after $72 \mathrm{hr}$ in $650 \mathrm{~F}$ water. 


\section{CONFIDENTIAL}

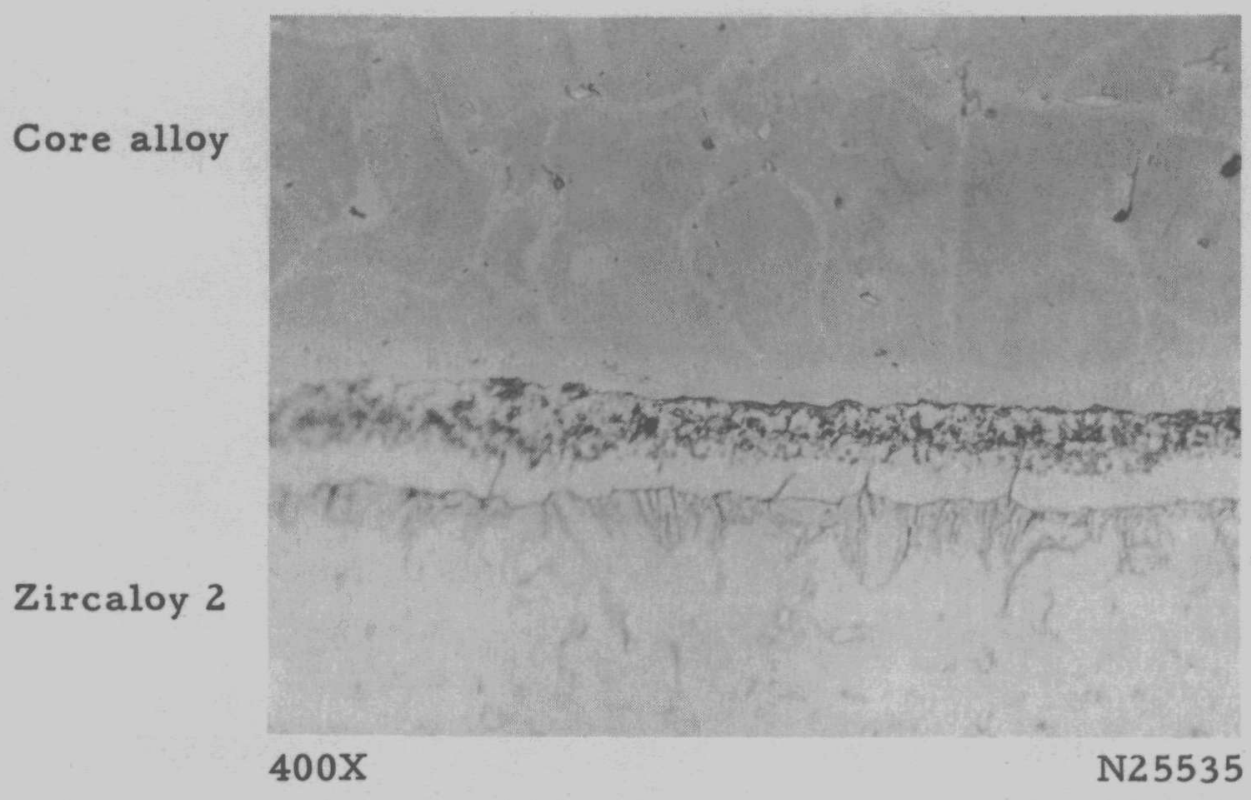

FIGURE 32. AS-BONDED NICKEL-TRANSITION-LAYER SPECIMEN PRESSURE BONDED AT $1300 \mathrm{~F}$ USING 600 PSI FOR $1 / 2$ HR

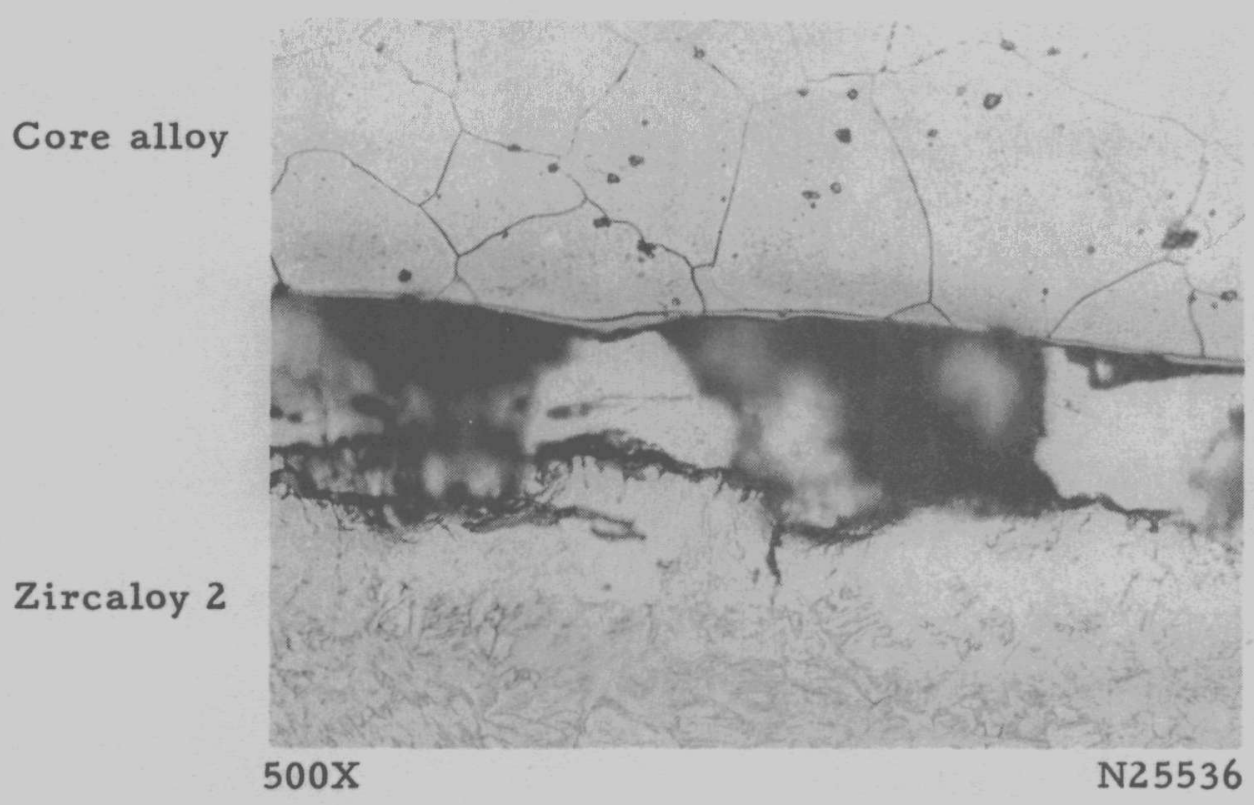

FIGURE 33. AS-FAILED NICKEL-TRANSITION-LAYER SPECIMEN CORROSION TESTED FOR 72 HR IN $650 \mathrm{~F}$ WATER

Failure occurred in the transition layer as in adjacent diffusion layers. 


\section{CONFIDENTIAL}

36

Core alloy

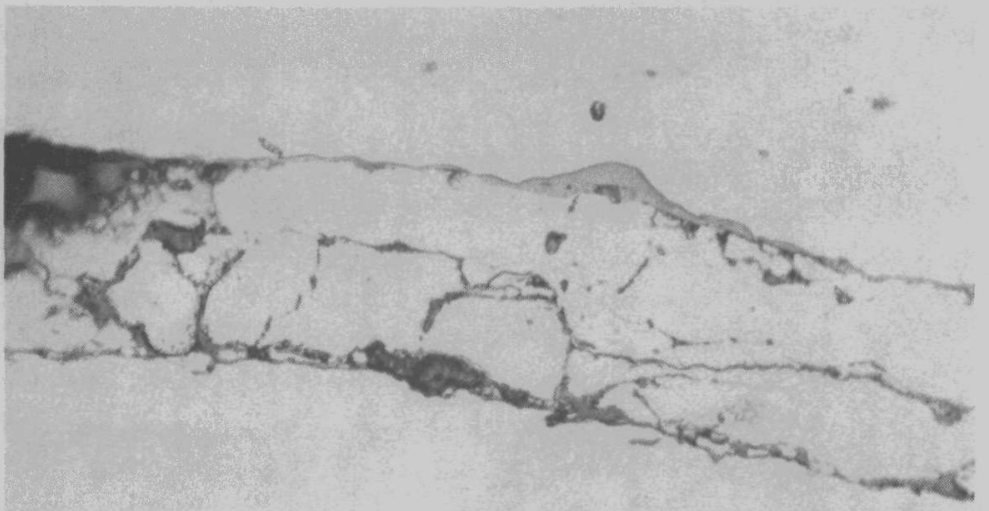

Zircaloy 2

$500 \mathrm{X}$

N25537

FIGURE 34. AS-FAILED CHROMIUM-TRANSITION-LAYER SPECIMEN CORROSION TESTED FOR $168 \mathrm{HR}$ IN $650 \mathrm{~F}$ WATER

Failure in transition layer.

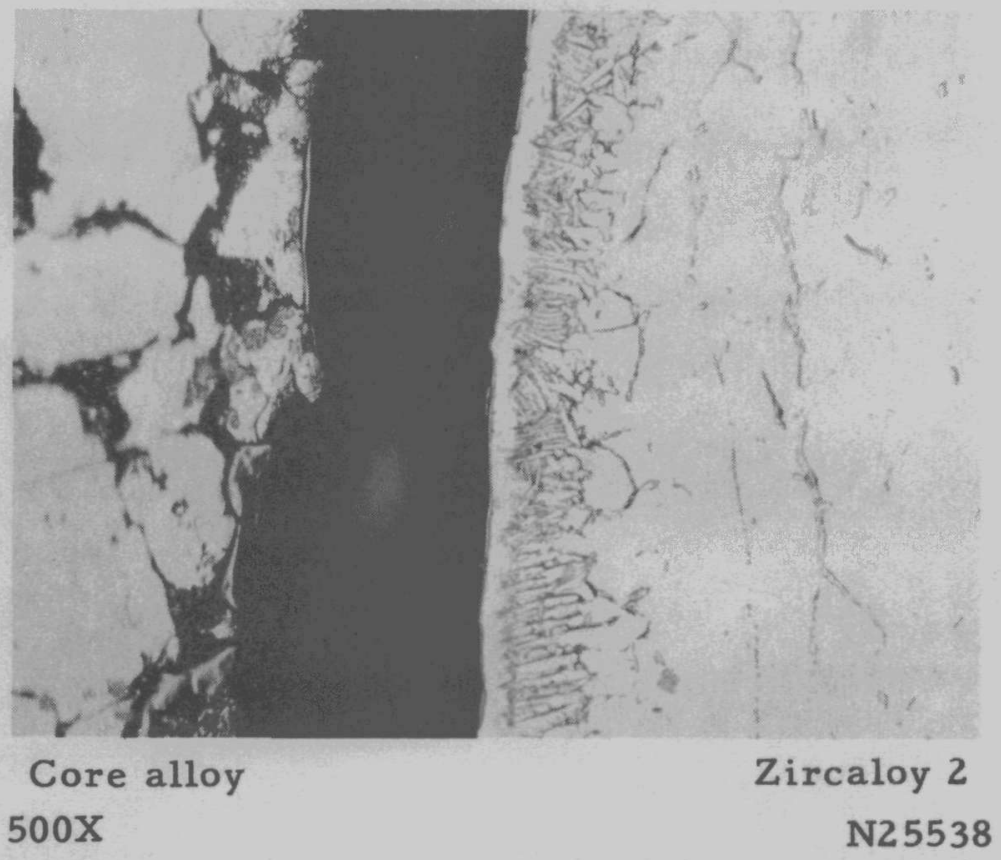

FIGURE 35. AS-FAILED IRON-TRANSITION-LAYER SPECIMEN CORROSION TESTED FOR 72 HR IN 650 F WATER

Failure in transition layer in diffusion layers adjacent to the core.

WOTWLENTIAL 


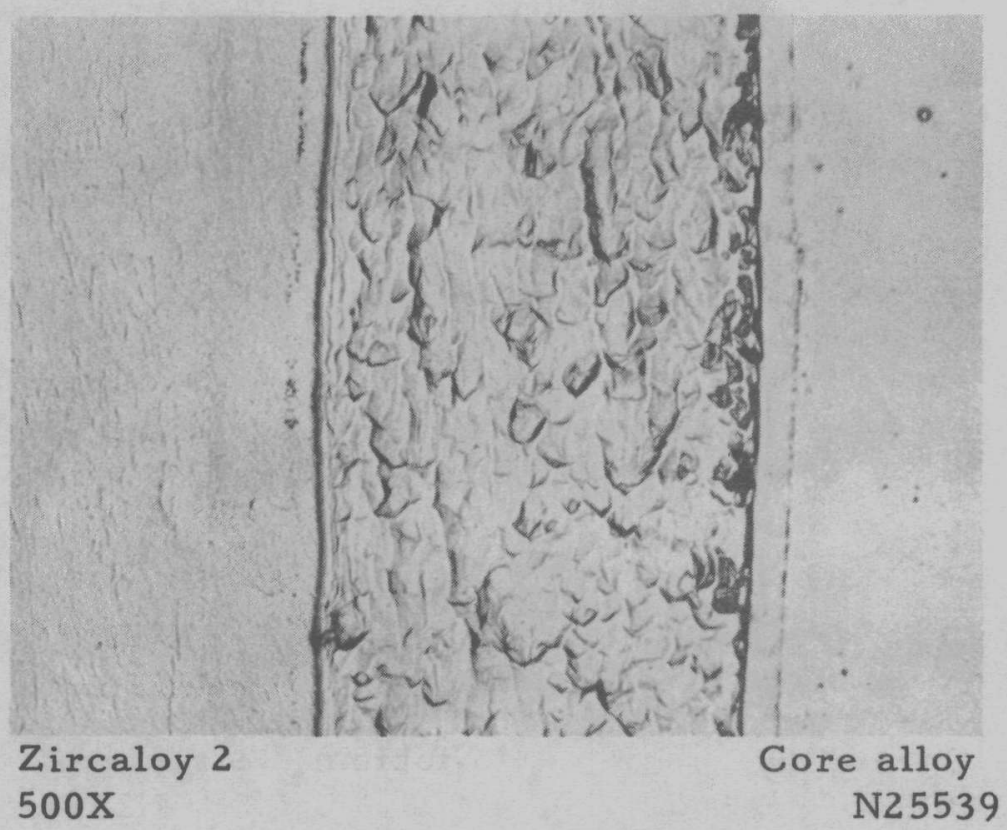

FIGURE 36. AS-BONDED MOLYBDENUM-TRANSITION-LAYER SPECIMEN PRESSURE BONDED AT $1400 \mathrm{~F}$ USING 600 PSI FOR $4 \mathrm{HR}$

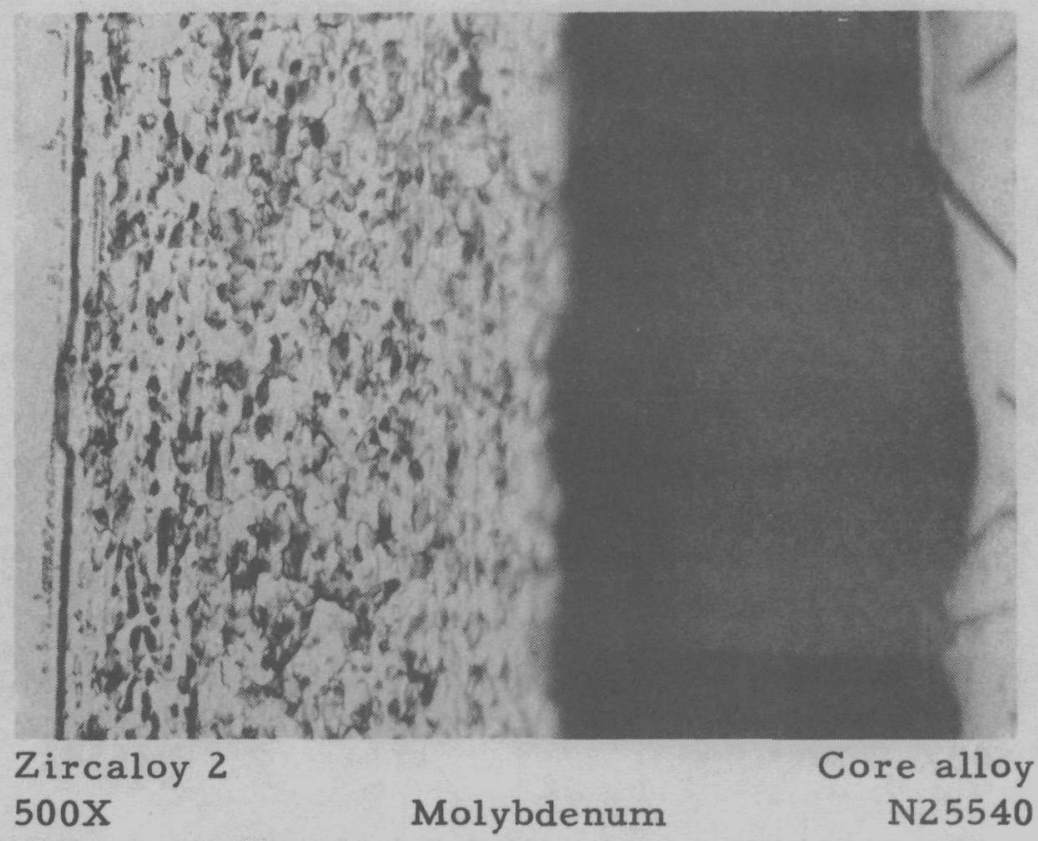

FIGURE 37. AS-FAILED MOLYBDENUM-TRANSITION-LAYER SPECIMEN CORROSION TESTED FOR 72 HR IN $650 \mathrm{~F}$ WATER

Failure in diffusion layer formed between transition layer and core.

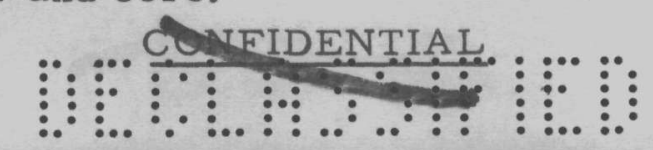




\section{CONFIDENTIAL}

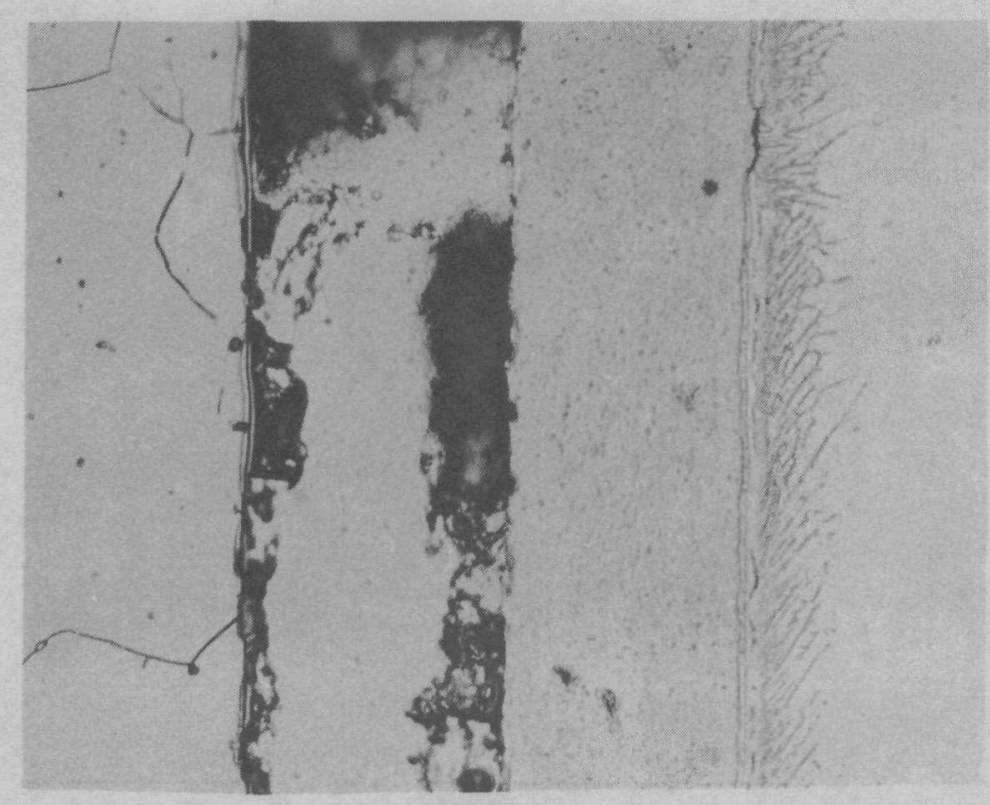

Core alloy $500 \mathrm{X}$

Niobium Zircaloy 2 N25541

FIGURE 38. AS-FAILED NIOBIUM-TRANSITION-LAYER SPECIMEN CORROSION TESTED FOR 72 HR IN 650 F WATER Failure in diffusion layer formed between transition layer and core.

Core alloy
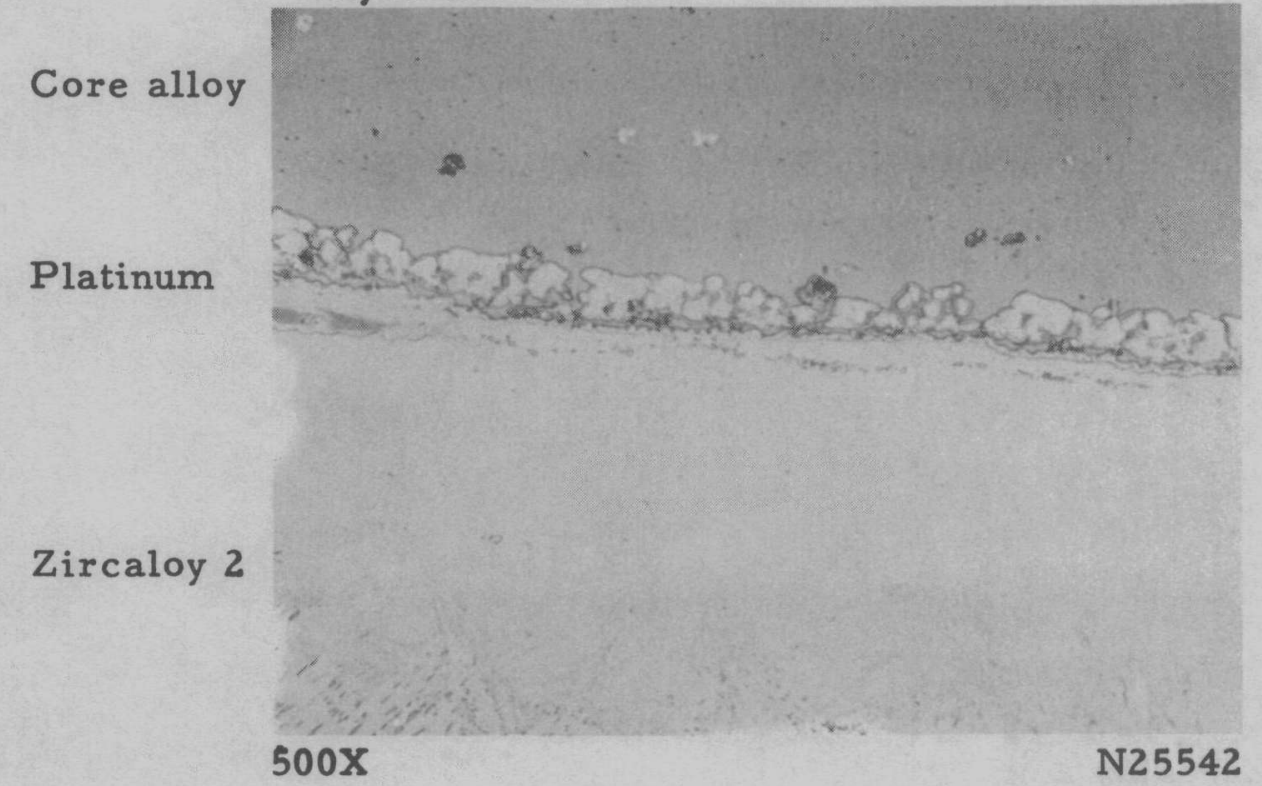

FIGURE 39. AS-BONDED PLATINUM-TRANSITION-LAYER SPECIMEN BONDED AT $1500 \mathrm{~F}$ USING 600 PSI FOR $1 \mathrm{HR}$

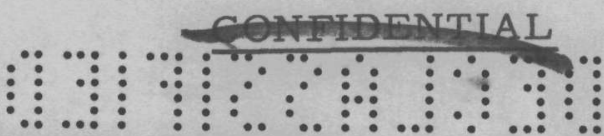


Improved corrosion resistance of the interface between core and cladding was obtained with an 0.0005-in. intermediate layer of platinum. A pressure of $600 \mathrm{psi}$ at $1500 \mathrm{~F}$ for $1 \mathrm{hr}$ was used to bond the platinum to the core and cladding. The character of the bond obtained with these conditions is exhibited in Figure 39. The ir regular diffusion zone obtained during pressure bonding may explain, in part, why the corrosion resistance of the interface was not improved more extensively by the addition of the platinum transition layer.

Tantalum transition layers produced the most improvement of any of the refractory metals investigated. A layer of $0.002-i n$. tantalum foil was bonded to core and cladding at $1400 \mathrm{~F}$, using $600 \mathrm{psi}$ for $4 \mathrm{hr}$. Strong metallurgical bonds were obtained with these bonding conditions. After $168 \mathrm{hr}$ of testing in high-temperature water, a high rate of attack had developed, but complete failure of the specimen had not occurred. A segment taken from an area still intact is illustrated in Figure 40. Segments taken from areas of failure indicated failure occurred in the diffusion layer formed between the tantalum and the core.

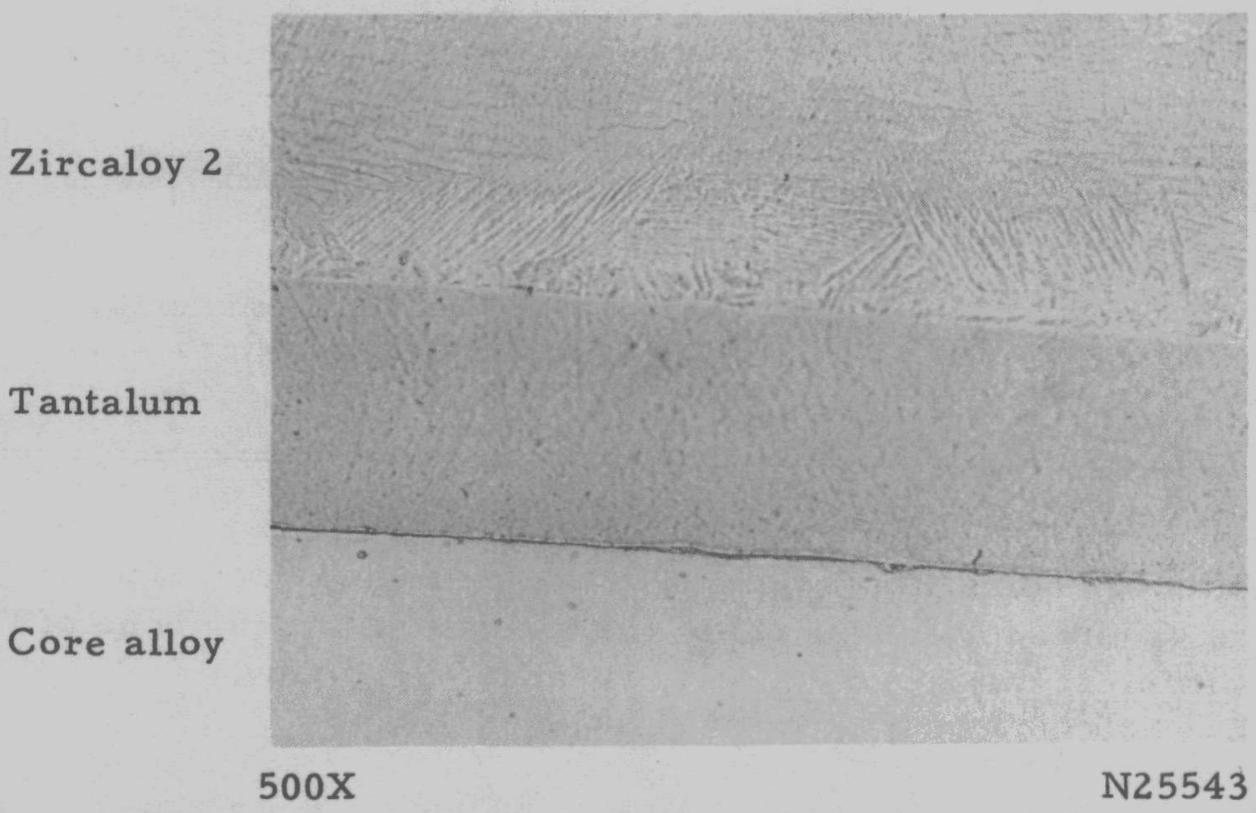

FIGURE 40. INTACT AREA FROM AS-FAILED TANTALUMTRANSITION-LAYER SPECIMEN PRESSURE BONDED AT 1400 F USING 600 PSI FOR 4 HR AND CORROSION TESTED 168 HR IN $650 \mathrm{~F}$ WATER 
Uranium-10 w/o niobium foil was prepared from an arc-melted ingot. The ingot was hot rolled at $1800 \mathrm{~F}$ bare and at $1250 \mathrm{~F}$ in a steel pack to 0.008-in. foil. Various bonding conditions were attempted in an effort to vary the diffusion interface formed between the uranium-10 w/o niobium and the core and cladding. All of the pressure-bonded specimens failed after $72 \mathrm{hr}$ of testing in high-temperature water.

The manner in which the transition-layer specimens failed is summarized in Table 5.

TABLE 5. TRANSITION-LA YER FAILURE

\begin{tabular}{|c|c|}
\hline Transition Layer & Manner of Failure \\
\hline Chromium & Failure in the transition layer by cracking \\
\hline Iron & $\begin{array}{l}\text { Failure in the transition layer and entire } \\
\text { diffusion interface }\end{array}$ \\
\hline Molybdenum & $\begin{array}{l}\text { Failure in diffusion layers between transition } \\
\text { layer and core }\end{array}$ \\
\hline Nickel & $\begin{array}{l}\text { Failure in the transition layer and entire } \\
\text { diffusion interface }\end{array}$ \\
\hline Niobium & $\begin{array}{l}\text { Failure in diffusion layers between transition } \\
\text { layer and core }\end{array}$ \\
\hline Platinum & $\begin{array}{l}\text { Failure in irregular transition layer and in } \\
\text { layers formed between transition layer } \\
\text { and the core }\end{array}$ \\
\hline Tantalum & $\begin{array}{l}\text { Failure in diffusion layer formed between } \\
\text { transition layer and core }\end{array}$ \\
\hline Uranium $-10 \mathrm{w} / \mathrm{o}$ niobium & $\begin{array}{l}\text { Failure over entire interface formed during } \\
\text { bonding except for two layers adjacent } \\
\text { to cladding }\end{array}$ \\
\hline
\end{tabular}

Although some improvement in the corrosion resistance of the interface was observed with several of the transition layers, none of them produced sufficient improvement to warrant further study.

Intermediate Layers Between Zircaloy 2 and Uranium-3.8 w/o Silicon

Although the corrosion resistance of a uranium-3. $8 \mathrm{w} / 0$ silicon alloy in the epsilonized condition is promising, the interface formed between the epsilonized alloy and Zircaloy 2 cladding is not corrosion resistant to $650 \mathrm{~F}$ water. In an effort to minimize the interdiffusion between the core and cladding and thereby alter the corrosion properties of the interface, transition

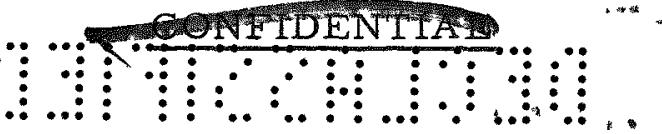


bonding layers were investigated. The rate of diffusion between transition layers and the core and cladding was determined. Corrosion properties of the formed interfaces were not studied.

A 25-1b ingot of uranium-3.8 w/o silicon was prepared by the duplex induction-consumable electrode arc-melt process. The as-cast ingot was epsilonized by heat treating for 1 week at $1475 \mathrm{~F}$. Specimens for bonding studies were prepared from this material.

The poor fabrication properties of the epsilonized material, which is essentially all $\mathrm{U}_{3} \mathrm{Si}$ compound, prohibited direct fabrication of core specimens by forging or rolling. Cores $14 \mathrm{in.} \mathrm{thick} \mathrm{by} 1 \mathrm{in}$. square had to be cut and machined to size. Barrier layers were applied to the cores in the form of electroplates on foil before the cores were inserted in Zircaloy 2 frames. Zircaloy 2 covers, 0.050 in. thick, were employed to complete the assembly. The assemblies were pressure bonded at elevated temperatures for various periods of time under a constant load of 600 psi. The amount of interdiffusion was measured after pressure bonding at temperature for time intervals of $1 / 4,1,4$, and $8 \mathrm{hr}$.

Sections taken from the bonded specimens were inspected by metallographic techniques to determine the amount of diffusion between the barrier layer, the cladding, and the core. All components of the assembled fuel elements were measured before and after bonding to verify the continuity of the measurements made on the interface. The average thickness of the diffusion zone between barrier and core, and barrier and cladding was plotted against the square root of time in hours, resulting in straight-line graphs.

Thus, the diffusion data fit the relation

$$
\begin{aligned}
& d=K \sqrt{t}, \text { where } \\
& d=\text { thickness, } i n . \\
& t=\text { time, } h r \\
& K=\text { proportionability constant. }
\end{aligned}
$$

The values of $\mathrm{K}$ were calculated for each of the barrier layers, and are given in Table 6. 
TABLE 6. BARRIER-LA YER DATA

\begin{tabular}{llcc}
\hline \multicolumn{1}{c}{$\begin{array}{c}\text { Barrier } \\
\text { Layer }\end{array}$} & $\begin{array}{c}\text { Mode of } \\
\text { Application }\end{array}$ & $\begin{array}{c}\text { Diffusion Constant, } \\
\text { Core and Barrier Layer, } \\
10^{-5} \text { in. } / \sqrt{\mathrm{hr}}\end{array}$ & $\begin{array}{c}\text { Diffusion Constant, } \\
\text { Cladding and Barrier Layer, } \\
10^{-5} \text { in. } / \sqrt{\mathrm{hr}}\end{array}$ \\
\hline Copper & 1 -mil electroplate & 150 & 70 \\
Molybdenum & 4 -mil foil & 36 & 52 \\
Niobium & $1-$ mil foil & 5 & 42 \\
Platinum & $0.5-$ mil foil & 153 & 200 \\
Tantalum & $2-$ mil foil & 5 & 4 \\
\hline
\end{tabular}

The data in the table was obtained from an average of ten measurements made at random points across each interface. Measurements were made on as-polished and as-etched sections.

Specimens with barrier layers of molybdenum, niobium, platinum, and tantalum were all subjected to the same pressure-bonding temperature of $1700 \mathrm{~F}$ for time intervals of $1 / 4,1,4$, and $8 \mathrm{hr}$. Photomicrographs of the niobium, platinum, and tantalum series are shown in Figures 41 through 52. The tantalum served as the most effective barrier investigated while the niobium was of average effectiveness and the platinum was the most reactive with the core and cladding. Molybdenum is not illustrated, but it falls in the average effectiveness classification.

A series of copper-barrier specimens was pressure bonded at $1600 \mathrm{~F}$ using 600 psi for time intervals identical to those used for the refractorymetal series. The copper-barrier interface was the least ductile and contained alloy layers covering a wide range in hardness.

This transition-layer investigation was only exploratory and points out the effectiveness of tantalum as a barrier when compared with the other barriers tested. Time did not permit an investigation of additional barrier layers or determination of corrosion properties. 
Zircaloy 2
Tantalum
Uranium-3. $8 \mathrm{w} / \mathrm{o}$ silicon

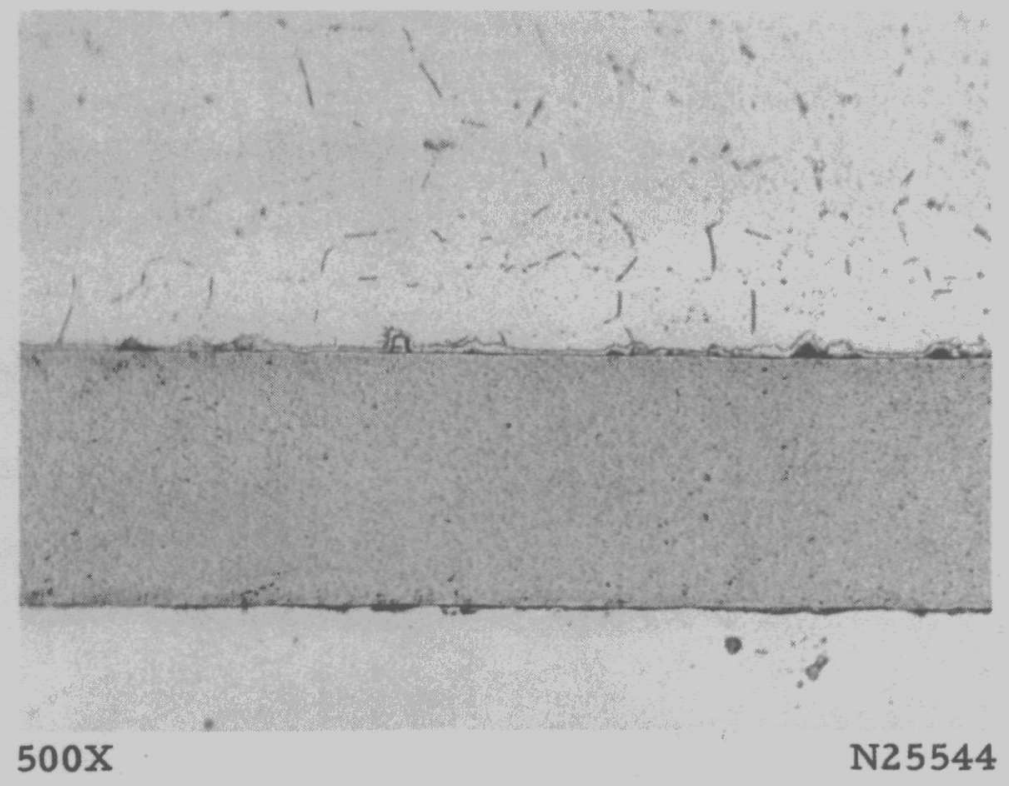

FIGURE 41. TANTALUM-BARRIER SPECIMEN PRESSURE BONDED AT 1700 F USING 600 PSI FOR 1/4 HR

Zircaloy 2

T antalum

Uranium-3. $8 \mathrm{w} / \mathrm{o}$
silicon

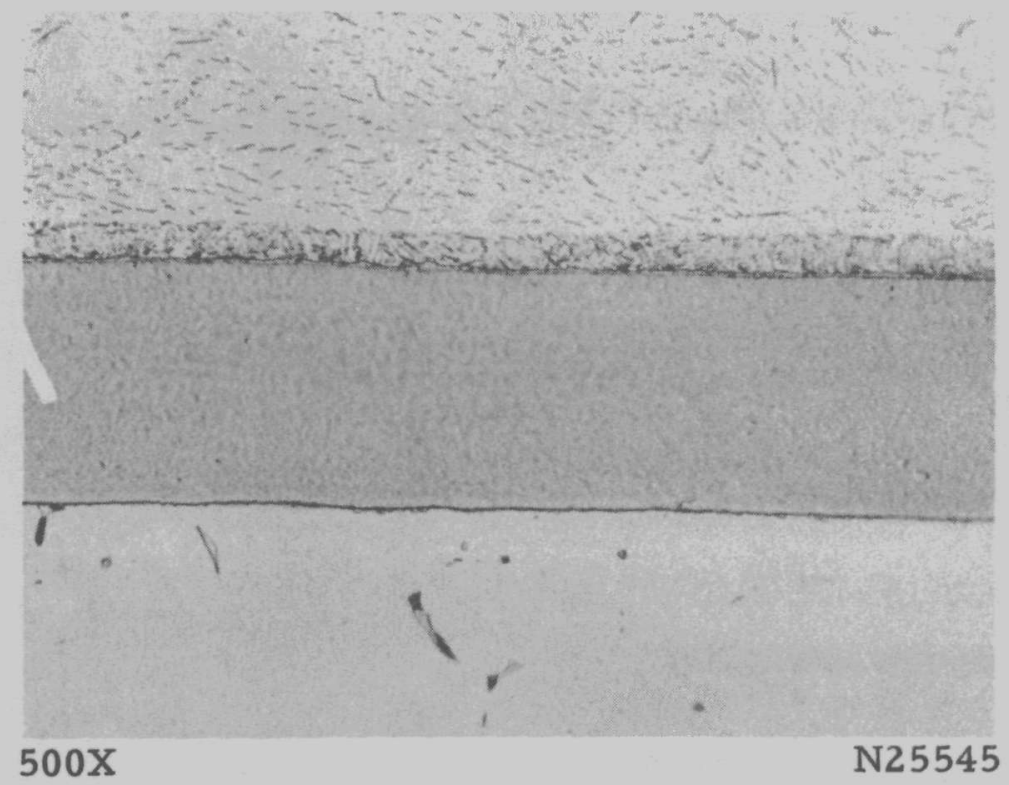

FIGURE 42. TANTALUM-BARRIER SPECIMEN PRESSURE BONDED AT 1700 F USING 600 PSI FOR 1/4 HR 
Zircaloy 2

Tantalum

Uranium-3. $8 \mathrm{w} / \mathrm{o}$ silicon

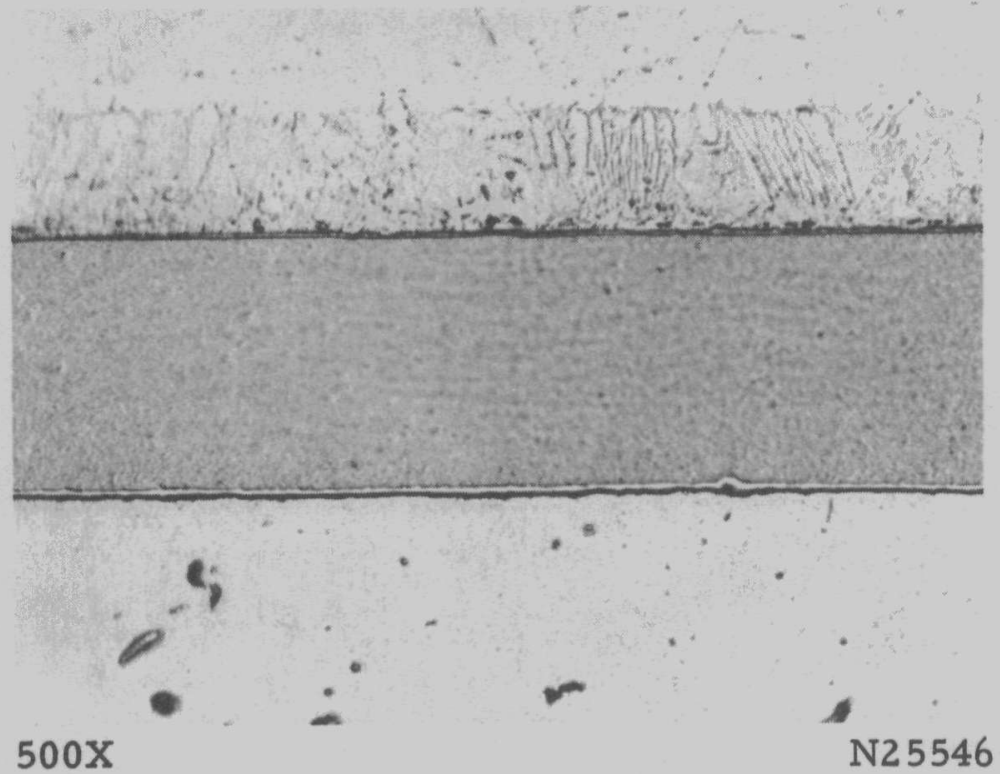

FIGURE 43. TANTALUM-BARRIER SPECIMEN PRESSURE BONDED AT 1700 F USING 600 PSI FOR 4 HR

Zircaloy 2

Tantalum

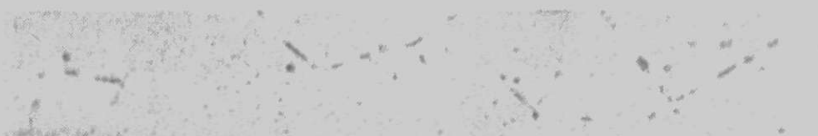
Tantalum
Uranium-3. $8 \mathrm{w} / \mathrm{o}$ silicon

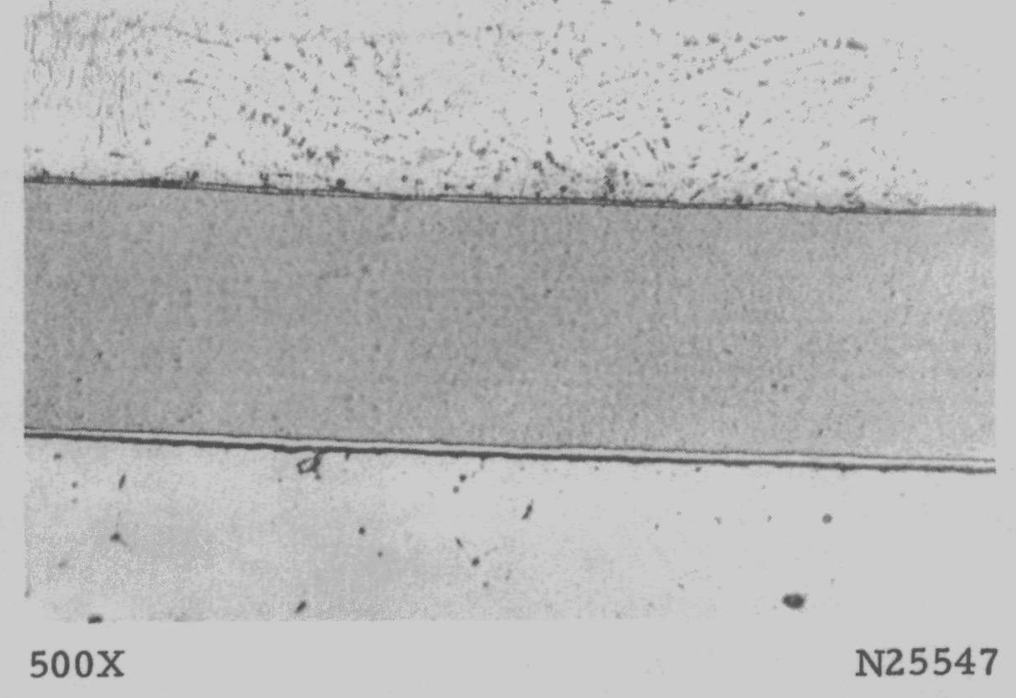

FIGURE 44. TANTALUM-BARRIER SPECIMEN PRESSURE BONDED AT 1700 F USING 600 PSI FOR 8 HR 
Zircaloy 2

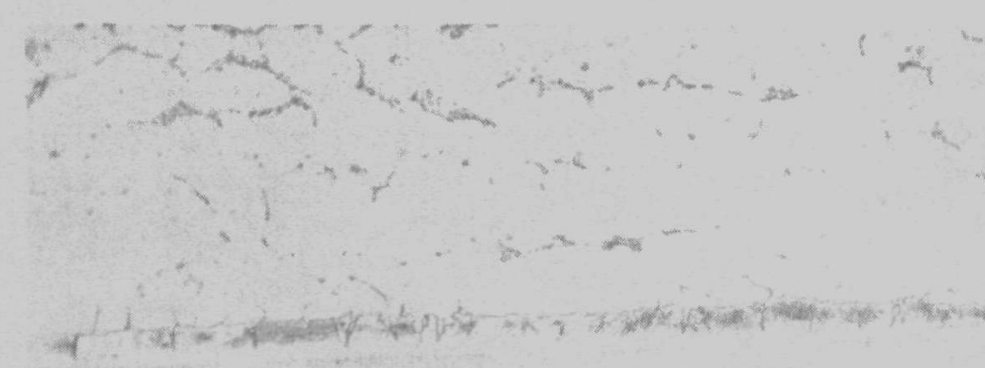

Niobium

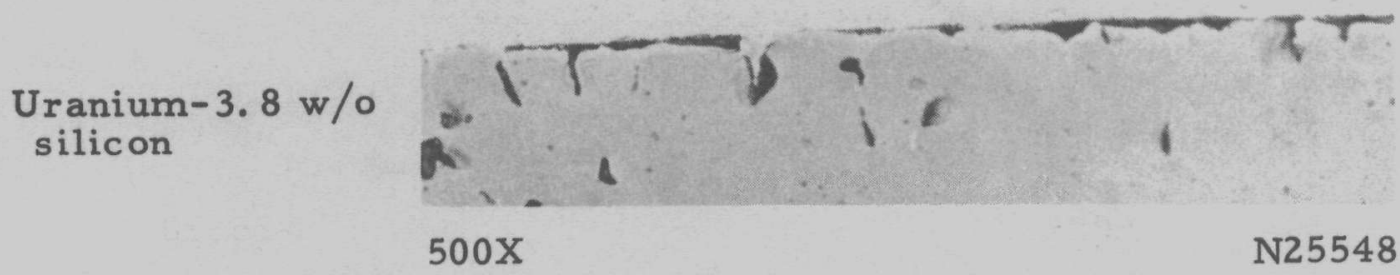

FIGURE 45. NIOBIUM-BARRIER SPECIMEN PRESSURE BONDED AT 1700 F USING 600 PSI FOR $1 / 4 \mathrm{HR}$

Zircaloy 2

Niobium

Uranium-3. $8 \mathrm{w} / \mathrm{o}$ silic on
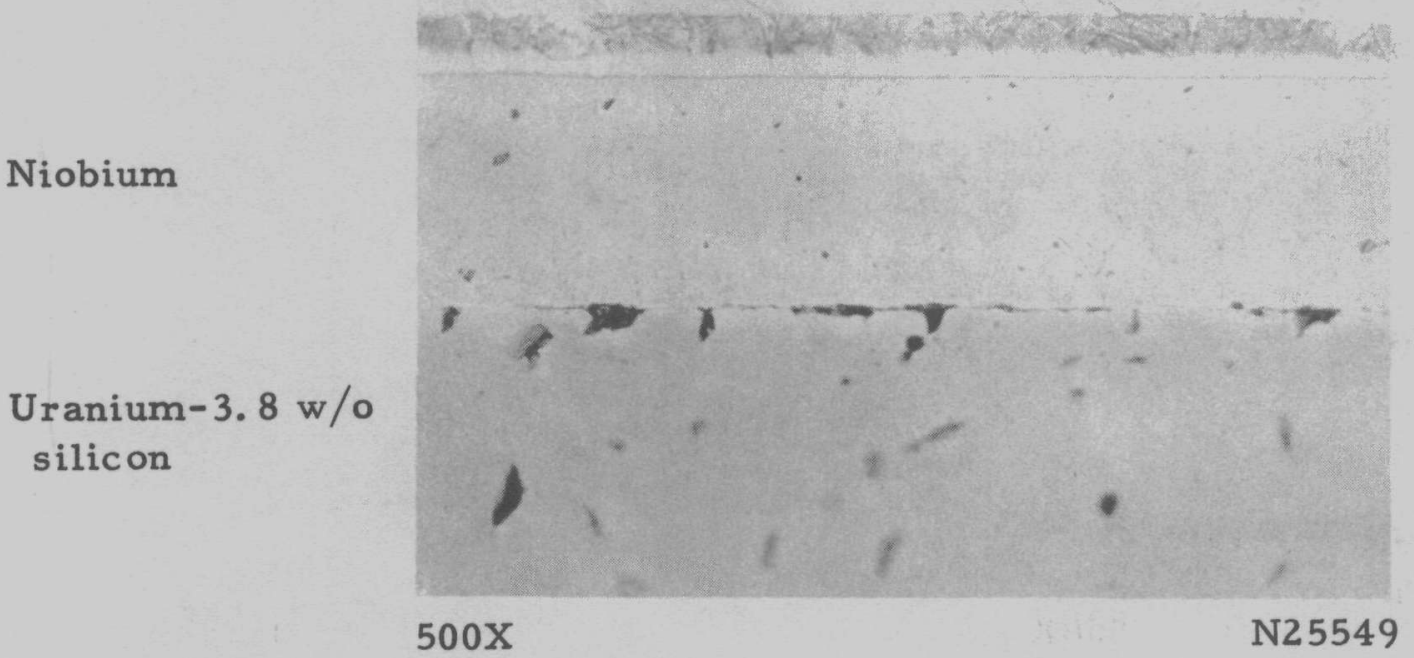

FIGURE 46. NIOBIUM-BARRIER SPECIMEN PRESSURE BONDED AT 1700 F USING 600 PSI FOR 1 HR 
Zircaloy 2

Niobium

Uranium-3. $8 \mathrm{w} / \mathrm{o}$ silicon
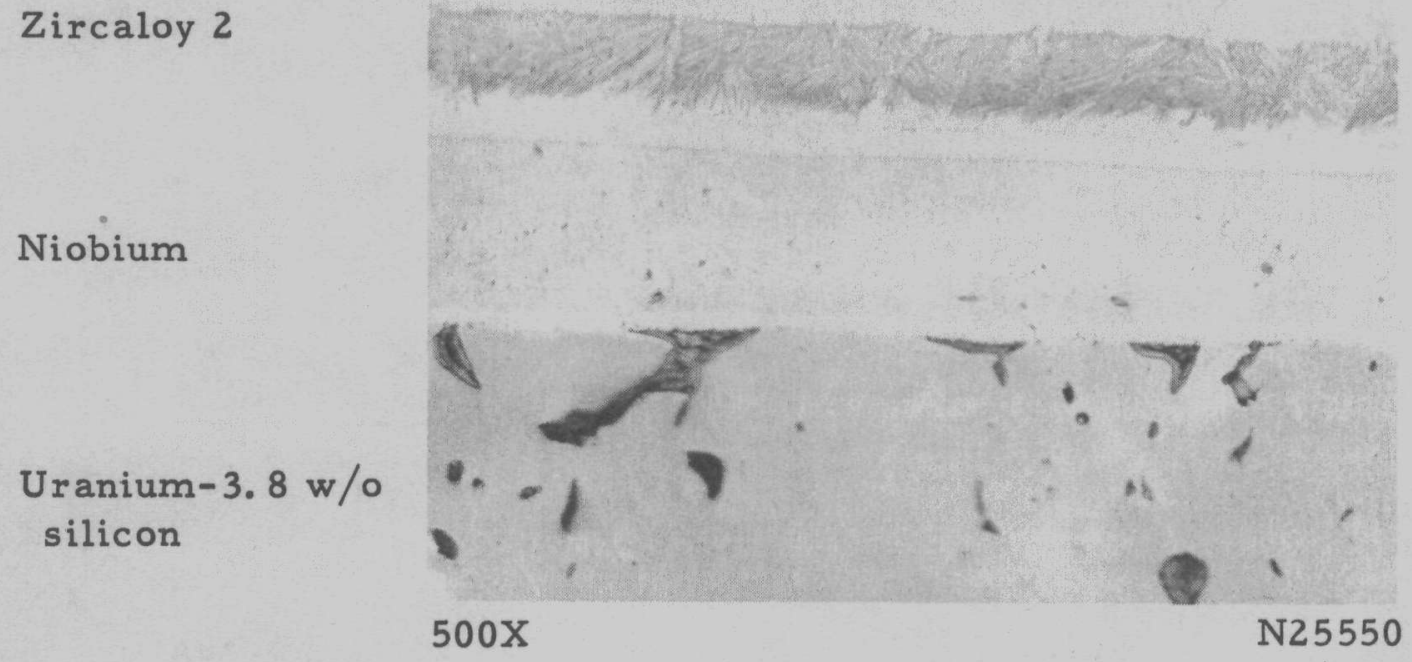

FIGURE 47. NIOBIUM-BARRIER SPECIMEN PRESSURE BONDED AT 1700 F USING 600 PSI FOR 4 HR

Zircaloy 2
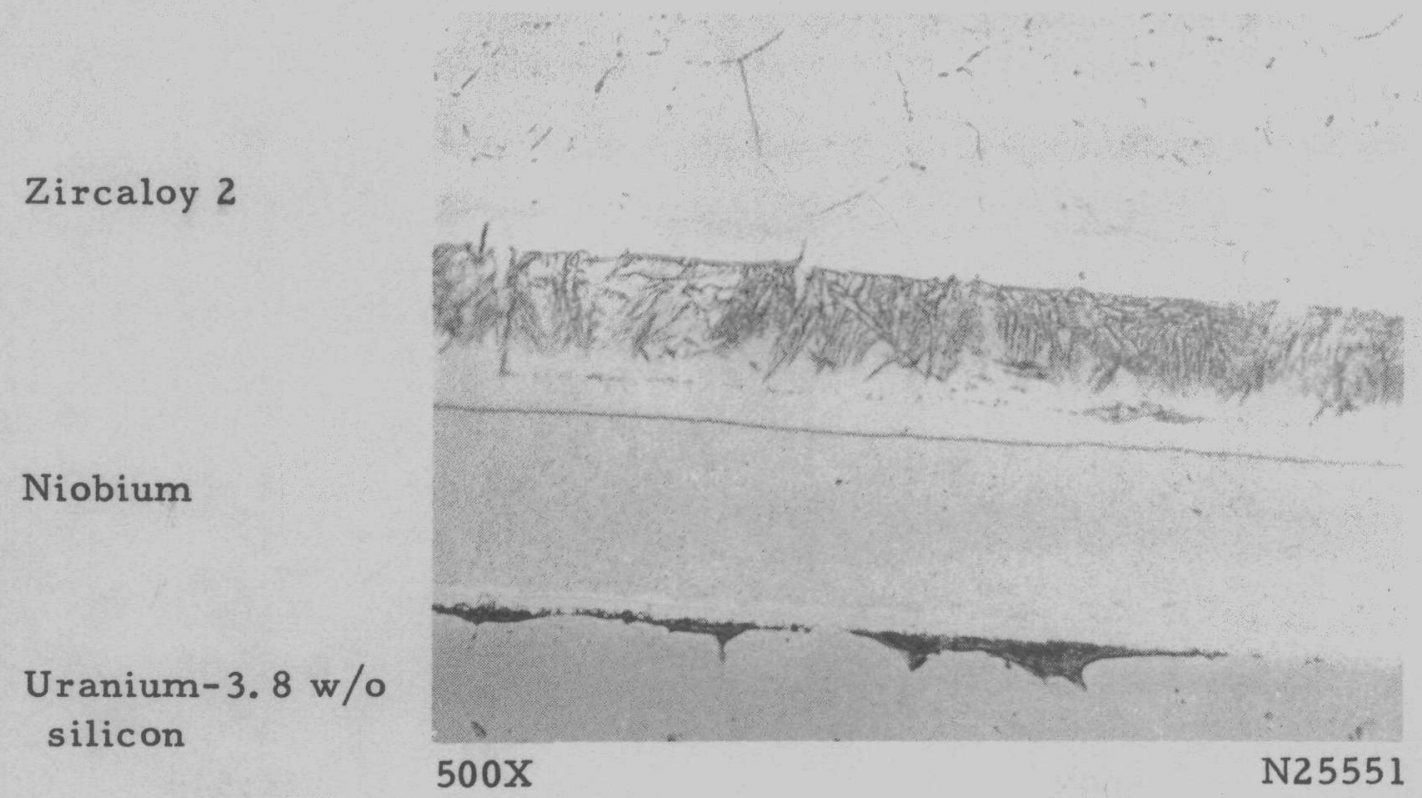

FIGURE 48. NIOBIUM-BARRIER SPECIMEN PRESSURE BONDED AT 1700 F USING 600 PSI FOR 8 HR 
Zircaloy 2

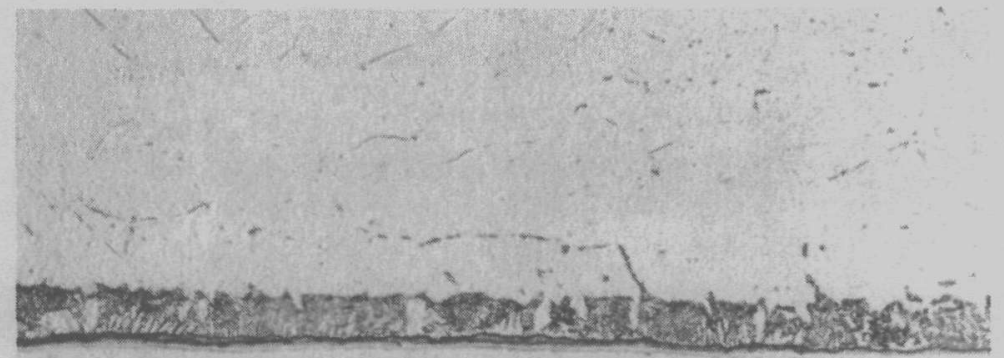

Platinum

Uranium-3. $8 \mathrm{w} / \mathrm{o}$ silicon

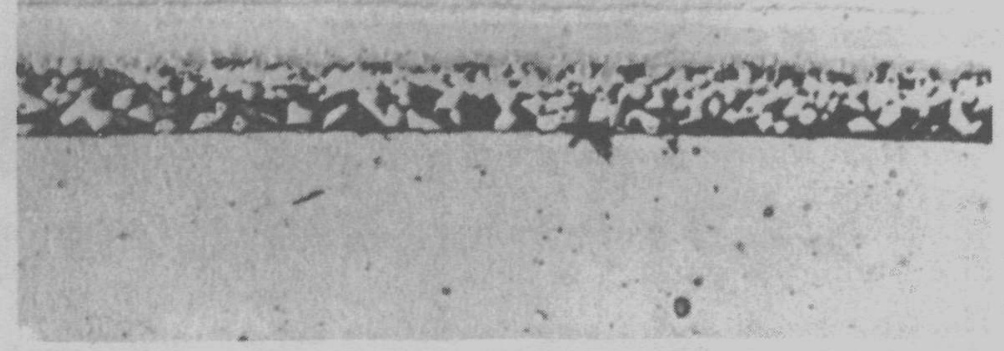

$500 x$

N25552

FIGURE 49. PLATINUM-BARRIER SPECIMEN PRESSURE BONDED AT 1700 F USING 600 PSI FOR $1 / 4$ HR

Zircaloy 2

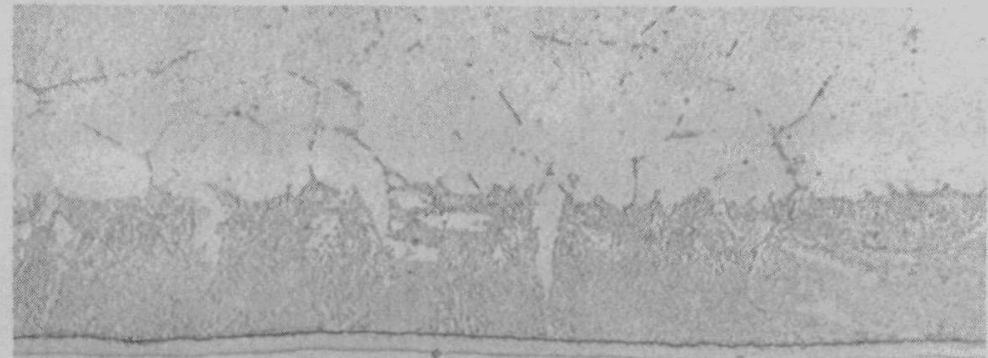

Platinum

Uranium-3. $8 \mathrm{w} / \mathrm{o}$ silic on

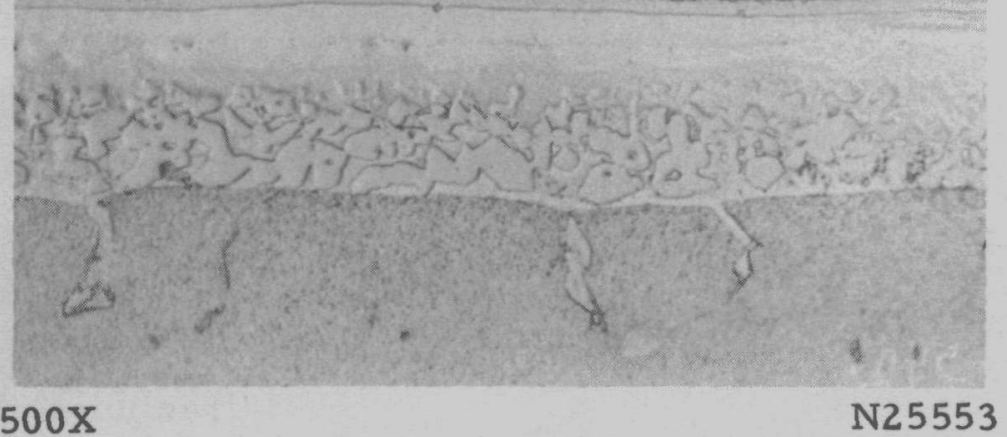

FIGURE 50. PLATINUM-BARRIER SPECIMEN PRESSURE BONDED AT 1700 F USING 600 PSI FOR 1 HR 


\section{CONFIDENTIAL}

48

Zircaloy 2

Platinum

Platinum
Uranium- $3.8 \mathrm{w} / \mathrm{o}$
silicon

Platinum
Uranium- $3.8 \mathrm{w} / \mathrm{o}$
silicon
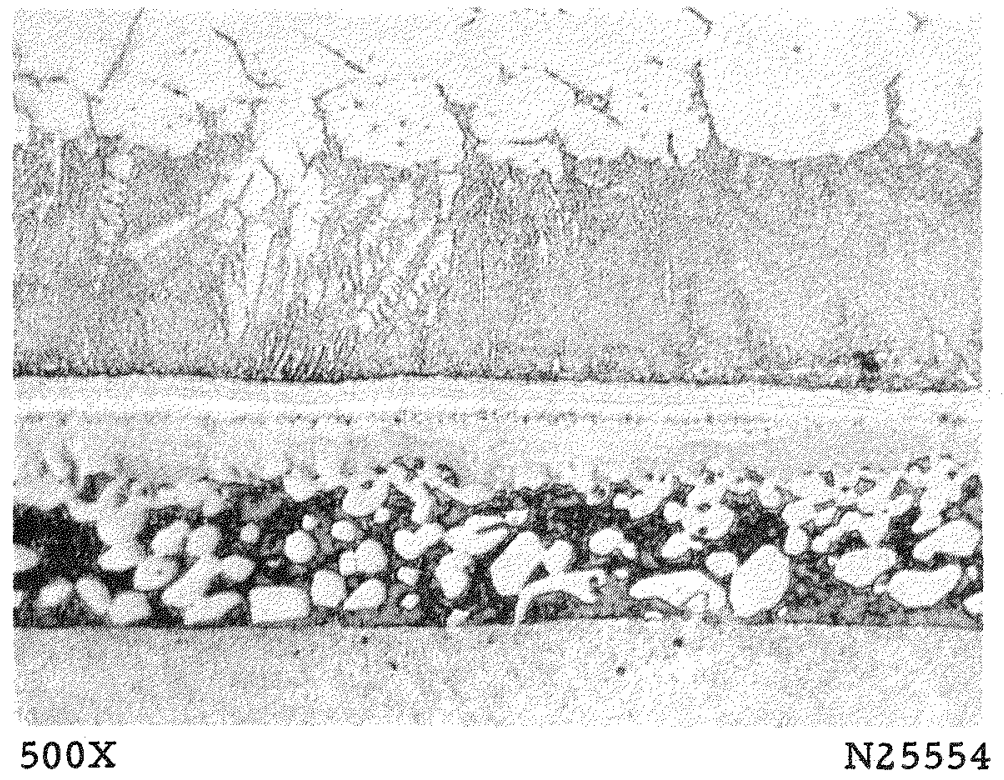

FIGURE 51. PLATINUM-BARRIER SPECIMEN PRESSURE BONDED AT 1700 F USING 600 PSI FOR $4 \mathrm{HR}$

Zircaloy 2

Platinum

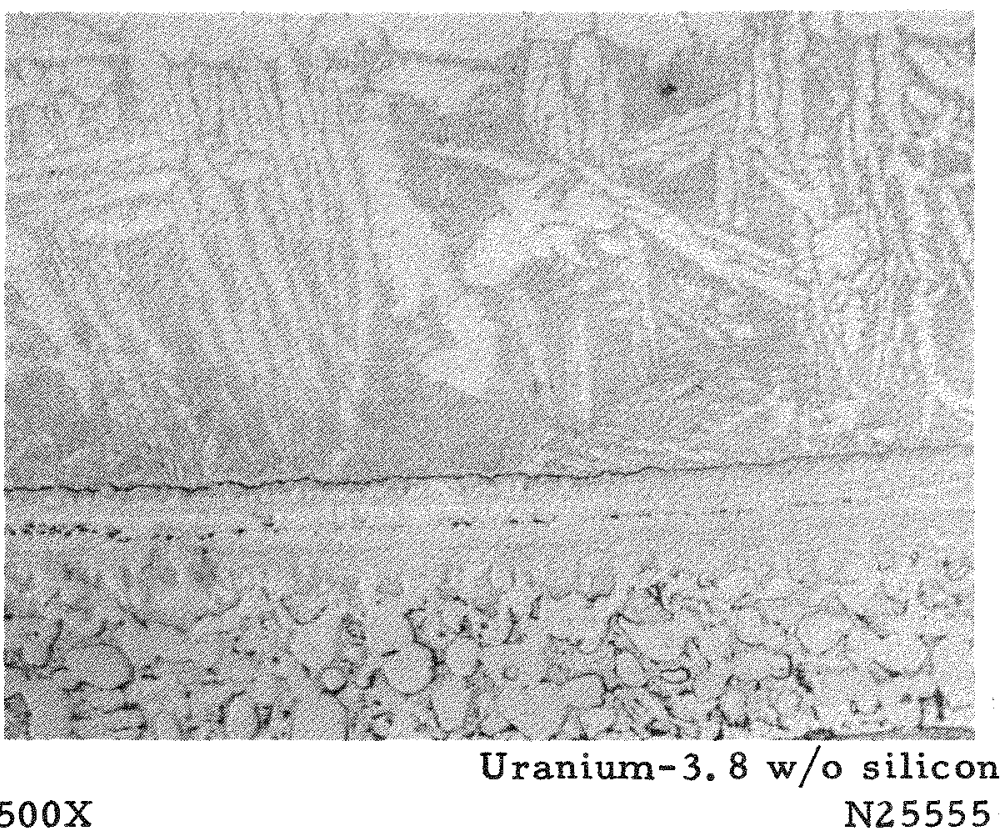

FIGURE 52. PLATINUM-BARRIER SPECIMEN PRESSURE BONDED AT 1700 F USING 600 PSI FOR 8 HR

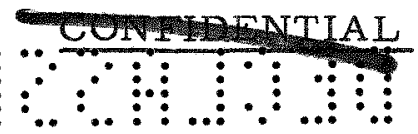




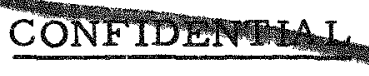

49 and 50

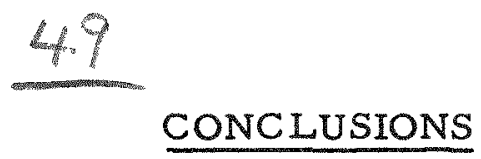

This investigation clearly revealed that a metallurgical bond with a minimum amount of diffusion between Zircaloy 2 and uranium-12 w/o molybdenum core alloy was the most desirable bonding condition for use in a pressurized high-temperature water environment. A relatively small amount of diffusion at the interface sharply reduced the corrosion properties of the bond. Extensive diffusion between core and cladding resulted in severe attack of the interface in a short exposure time in $650 \mathrm{~F}$ water. Heat treatments and the use of various transition layers were ineffective in preventing attack.

In the investigation of barrier layers, to minimize diffusion between Zircaloy 2 and uranium $-3.8 \mathrm{w} / \mathrm{o}$ silicon, tantalum was found to be the most effective. Only copper, molybdenum, niobium, platinum, and tantalum were investigated. Corrosion tests were not conducted to determine the effectiveness of the resultant interfaces in high-temperature, pressurized water.

HAS:SJP:ESH/s S

CONFHENTIAL 